\title{
Oral Administration of a Small Molecule Targeted to Block proNGF Binding to 75 Promotes Myelin Sparing and Functional Recovery after Spinal Cord Injury
}

\author{
Chhavy Tep, ${ }^{1,3}$ Tae Hee Lim, ${ }^{1}$ Pyung On Ko, ${ }^{1}$ Sami Getahun, ${ }^{1}$ Jae Cheon Ryu, ${ }^{1}$ Virginia M. Goettl, ${ }^{1}$ Stephen M. Massa, ${ }^{4}$ \\ Michele Basso, ${ }^{2}$ Frank M. Longo, ${ }^{5}$ and Sung Ok Yoon ${ }^{1}$ \\ Departments of ${ }^{1}$ Molecular and Cellular Biochemistry, and ${ }^{2}$ Physical Therapy, and ${ }^{3}$ Biochemistry Program, The Ohio State University, Columbus, Ohio \\ 43210, ${ }^{4}$ Department of Neurology, University of California at San Francisco, San Francisco, California 94121, and ${ }^{5}$ Department of Neurology and \\ Neurological Science, Stanford University, Stanford, California 94305
}

The lack of effective therapies for spinal cord injury points to the need for identifying novel targets for therapeutic intervention. Here we report that a small molecule, LM11A-31, developed to block proNGF-p75 interaction and p75-mediated cell death crosses the bloodbrain barrier efficiently when delivered orally. Administered starting $4 \mathrm{~h}$ postinjury, LM11A-31 promotes functional recovery without causing any toxicity or increased pain in a mouse model of spinal contusion injury. In both weight-bearing open-field tests and nonweight-bearing swim tests, LM11A-31 was effective in improving motor function and coordination. Such functional improvement correlated with a $>50 \%$ increase in the number of surviving oligodendrocytes and myelinated axons. We also demonstrate that LM11A-31 indeed inhibits proNGF-p75 interaction in vivo, thereby curtailing the JNK3-mediated apoptotic cascade. These results thus highlight p75 as a novel therapeutic target for an orally delivered treatment for spinal cord injury.

\section{Introduction}

Due to the complex nature of spinal cord injury (SCI), there are multiple obstacles that must be overcome before a meaningful functional recovery is achieved. The two most challenging obstacles are overcoming the physical barrier formed by glial scar and manipulating adult neurons into regaining the ability to extend long axons and form functional synapses (Busch and Silver, 2007; Sun and He, 2010). The blockade from glial scar formation has been overcome in part by injecting chondroitinase $\mathrm{ABC}$, which degrades chondroitin sulfate glycosaminoglycan chains (Bradbury et al., 2002), and genetic deletion of PTEN from neurons allowed regeneration (Park et al., 2008; Liu et al., 2010). Although these approaches were successful in animal models, where one can manipulate their genetic makeup or apply invasive strategies, the application of such approaches in human cases is not possible at the present time in the absence of easily deliverable reagents that target glial scar and the PTEN pathway.

\footnotetext{
Received Jan. 27, 2012; revised 0ct. 16, 2012; accepted 0ct. 18, 2012.

Author contributions: C.T. and S.O.Y. designed research; C.T., T.H.L., P.O.K., S.G., J.C.R., and V.M.G. performed research; S.M.M. and M.B. contributed unpublished reagents/analytic tools; C.T., F.M.L., and S.O.Y. analyzed data; C.T., F.M.L., and S.O.Y. wrote the paper.

This work was funded by grants from the National Institute of Neurological Disorders and Stroke (NINDS) (R01NS050585, R21NS059503) and the Christopher and Dana Reeve Foundation to S.0.Y., and The Ohio State Neuroscience Center Core from NINDS (P30NS045758). We thank Drs. Barbara Hempstead, Bruce Carter, and Elizabeth Coulson for providing p75 knock-out mice.

F.M.L. is a founder of PharmatrophiX, a company focused on the development of neurotrophin receptor ligands.

Correspondence should be addressed to Dr. Sung $0 \mathrm{k}$ Yoon, Department of Molecular and Cellular Biochemistry, 184 Rightmire Hall, Ohio State University, 1060 Carmack Road, Columbus, OH 43210. E-mail: Sung.yoon@osumc.edu.

DOI:10.1523/JNEUROSCI.0399-12.2013

Copyright $\odot 2013$ the authors $\quad 0270-6474 / 13 / 330397-14 \$ 15.00 / 0$
}

Myelinating oligodendrocytes have been recognized as an alternative target that can help improve functional recovery after SCI, mainly because they undergo chronic degeneration and cell death that lasts up to $450 \mathrm{~d}$ (Totoiu and Keirstead, 2005), allowing ample time for administering therapeutic agents. More importantly, the mode of their death was identified as apoptotic (Crowe et al., 1997) and its underlying mechanisms have been identified at the molecular level (McDonald et al., 1998; Kim et al., 2001; Beattie et al., 2002; Demjen et al., 2004; Li et al., 2007; Ohri et al., 2011). In addition, considering the fact that a single oligodendrocyte myelinates multiple axons, preventing the apoptosis of one oligodendrocyte could potentially spare many more axons (Crowe et al., 1997).

There have been two main strategies for improving oligodendrocyte survival after SCI. One is to reduce inflammation pharmacologically, thereby increasing oligodendrocyte survival (Yune et al., 2007; Kwon et al., 2011). Unfortunately, many of these drug therapies were not faithfully reproduced (Kwon et al., 2011). The lack of reproducibility may be in part due to the lack of a complete understanding of the target, and the still ill-defined role of inflammation in SCI (David and Kroner, 2011). The other popular approach is to replace lost oligodendrocytes by transplanting oligodendrocyte precursors that are derived from various sources with and without genetic modifications and growth factor supplements (Karimi-Abdolrezaee et al., 2006, 2010; Ohori et al., 2006; Biernaskie et al., 2007; Cao et al., 2010). A concern was raised in the transplantation approach, however, due to an apparent allodynia response despite improved functional recovery (Hofstetter et al., 2005). 
Here, we present a new, effective, noninvasive approach to promote oligodendrocyte survival and functional outcome after SCI. The strategy was based on targeted development of a nonpeptide small molecule, LM11A-31, which perturbs the interaction between proNGF and p75 and blocks the subsequent apoptotic response in oligodendrocytes in culture (Massa et al., 2006). When administered orally beginning $4 \mathrm{~h}$ after injury and twice daily thereafter, LM11A-31 prevented oligodendrocyte loss, thereby increasing the number of myelinated axons. These morphological changes were associated with improved functional recovery.

\section{Materials and Methods}

\section{P75 knock-out mice}

A congenic C57BL/6 line that carries a mutation in exon 3 of the p 75 gene was used for the study (Lee et al., 1992). Their genotype was determined by PCR analyses of tail DNA (Bentley and Lee, 2000).

\section{Spinal cord Injury and postoperative care}

For contusion injury, an Infinite Horizon Impactor (PSI) was used on adult C57BL/6 female mice that were 11-13 weeks old. Briefly, under deep anesthesia with ketamine and xylazine $(90 \mathrm{mg} / \mathrm{kg}$ and $10 \mathrm{mg} / \mathrm{kg}$, respectively, i.p.), mice received a dorsal laminectomy at the $\mathrm{T} 9$ position. All surgeries were performed under aseptic conditions. A controlled force-defined impact at $50 \mathrm{kdyne}$ was delivered to the exposed cord with a stainless steel impactor tip after securing the lateral processes of T8 and T10. If the actual force value after impact was $<50 \mathrm{kdyne}$, or if the actual displacement value of the impactor was outside of 400-600 $\mu \mathrm{m}$, the mouse was excluded. On the following day, if inadequate injury was indicated by a BMS score $>2$, the mouse was also excluded (average of $12.5 \%)$. After the impact, the mouse was visually inspected for evidence of adequate impact, primarily for bruising of the cord, and muscles were sutured and the skin stapled with surgical clamps. The mice were then injected subcutaneously with $0.5 \mathrm{ml}$ of buprenorphine $(0.1 \mathrm{mg} / \mathrm{kg}), 0.5$ $\mathrm{ml}$ of Baytril $(2.5 \mathrm{mg} / \mathrm{kg})$, and sterile saline at $2.5 \mathrm{ml} / 50 \mathrm{~g}$ weight. Saline and Baytril were administered daily for a week. The mice underwent gentle bladder expression twice daily until they were voiding on their own. Weight was monitored daily until $14 \mathrm{~d}$ postinjury (hereafter denoted as dpi), and then weekly for the duration of the experiments (42 dpi). A 10\% weight loss was typically observed after injury, and a high caloric nutrient paste (Nutrical; Evsco) was provided ad libitum as a dietary supplement. All procedures were performed in accordance with the Ohio State University Institutional Animal Care and Use Committee.

\section{Small molecule administration}

LM11A-31 was custom made for the present studies at AMRI Global. The lot used here was first characterized in in vitro studies to verify activity as described in (Massa et al., 2006). The determined drug dosages $(0,10,25$, and $100 \mathrm{mg} / \mathrm{kg}$ ) were aliquoted into a color-coded system, so as to maintain double-blinded measures. The color code was unveiled only after all the behavioral tests and analyses were completed. Mice were randomly assigned to each of the four treatment groups. The small molecule was administered via oral gavage, beginning $4 \mathrm{~h}$ after injury, and then twice daily until tissue harvests.

\section{BMS test for open-field locomotion}

Open-field locomotion was assessed with the BMS rating system, which was developed as a more sensitive and reliable measurement of hindlimb recovery in mice following SCI (Basso et al., 2006). The open field was a round table that was $20.32 \mathrm{~cm}$ high and $1.524 \mathrm{~m}$ in diameter situated in a quiet testing room with normal lighting. The mice were acclimated to the testing table for $20 \mathrm{~min}$ daily for a week before surgery. The day before surgery, the mice were tested to obtain baseline pre-op values, which showed no difference between the four different test groups. After injury, each mouse was observed at $1,3,5,7,10,14,21,28,35$, and $42 \mathrm{~d}$ to evaluate differences in functional recovery among different drug treatments. The extent of force applied in the contusion injuries was chosen to deliver moderate-severe thoracic contusions ( $50 \mathrm{kdyne}$ ) so as to allow some degree of weight-supported stepping in recovery. This also ensured that there was some extent of impairment in hindlimb function during overground walking.

Two individuals who were blind to the treatment groups simultaneously scored hindlimb locomotion for 4 min per mouse using the score sheet from Basso et al. (2006). If the scores differed between the individuals, the lower score was taken. To summarize the steps involved in BMS testing, it was first decided whether the mouse was plantar stepping when it was placed in the open field and the timer was initiated. If not, then ankle movement of dorsal stepping was evaluated and appropriately scored. If there was plantar stepping, then the frequency of stepping and coordination was evaluated according to Basso et al. (2006).

\section{Swim test}

To assess locomotor performance in the absence of the weight support, we observed the limb movement of the mice while they swam across a fish tank ( $85 \mathrm{~cm}$ long $\times 30 \mathrm{~cm}$ high $\times 30 \mathrm{~cm}$ deep), according to a rat protocol established by Liebscher et al. (2005) with modification for mice (Gullo et al., 2008). The water was $22 \mathrm{~cm}$ deep and kept at $32^{\circ} \mathrm{C}$, and a black acrylic divider was placed inside the tank to create a $12.7 \mathrm{~cm}$ wide swimming track that ran along the length of the aquarium so as to discourage the mice from swimming in circles. At the end of the swimming track, the mice were able to climb onto a platform that was exposed 2.54 $\mathrm{cm}$ above the water. To facilitate the videotaping of the paw positions during swimming, a mirror was placed against the divider to provide a $45^{\circ}$ angle from the underside of the mice during videotaping. Mice were acclimated to the swim tank for several minutes daily, a week before contusion injuries. At $42 \mathrm{~d}$ postinjury, mice were videotaped to obtain at least two passes of $44 \mathrm{~cm}$ long distance. Analysis included observations of the following parameters, each of which was given a score that was added up to give a total cumulative swimming score. It should be noted that tail movement was excluded from the total score calculation because it is in any event minor in mice, regardless of the fact that tails were mostly paralyzed after injury.

Hindpaw position. The hindpaws of uninjured mice are placed close to the midline of the body axis, but after injury, the hindpaws are positioned farther laterally. A score of 3 was given to the normal hindpaw position, while the most lateral hindpaw position was given a score of 1 .

Forelimb usage. Uninjured mice used forelimb usage only for steering of the body during swimming, while contused mice used forelimb strokes to propel themselves to compensate for the lack of hindlimb motion. Forelimb usage was given a score of 2 for mice that mostly used the forelimb for steering. A score of 1 was given to mice that used one forelimb at a time, while a score of 0 was given to mice that mostly used both forelimbs for propelling the body through the water.

Hindlimb coordination. The frequency of evenly crisscrossing left and right hindlimb strokes was quantified. For a score of 2 for most coordination, $>50 \%$ of the total strokes comprises even left and right hindlimb kicking, while for a score of 1 for some coordination, there were $<50 \%$ even strokes between the left and right hindlimbs. A score of 0 was given to mice exhibiting no coordination, which included no movement at all in the hindlimb, or uneven usage of only one hindlimb.

\section{Mechanical allodynia}

Mechanical sensitivity studies were conducted at $42 \mathrm{dpi}$, using the dynamic plantar aesthesiometer (Ugo Basile). It is an automated von Frey system that assesses the withdrawal threshold to graded mechanical pressure. Paw withdrawal thresholds were measured with an applied force that was initially below the detection threshold, and increased from 0 to $5 \mathrm{~g}$. When a withdrawal response occurred, the stimulus was terminated and the response threshold was recorded electronically. The force applied to elicit a reflex removal was recorded, and five measurements were taken, testing each hindpaw alternately, with at least 10-20 min intervals in between. A paw withdrawal threshold was calculated as the mean of the threshold of five trials.

\section{Hyperalgesia}

Heat Sensitivity at $52-54^{\circ} \mathrm{C}$ was tested at $42 \mathrm{dpi}$, using a modified Hargreaves Apparatus that emits infrared as a heat source upon contact (Ugo 
A
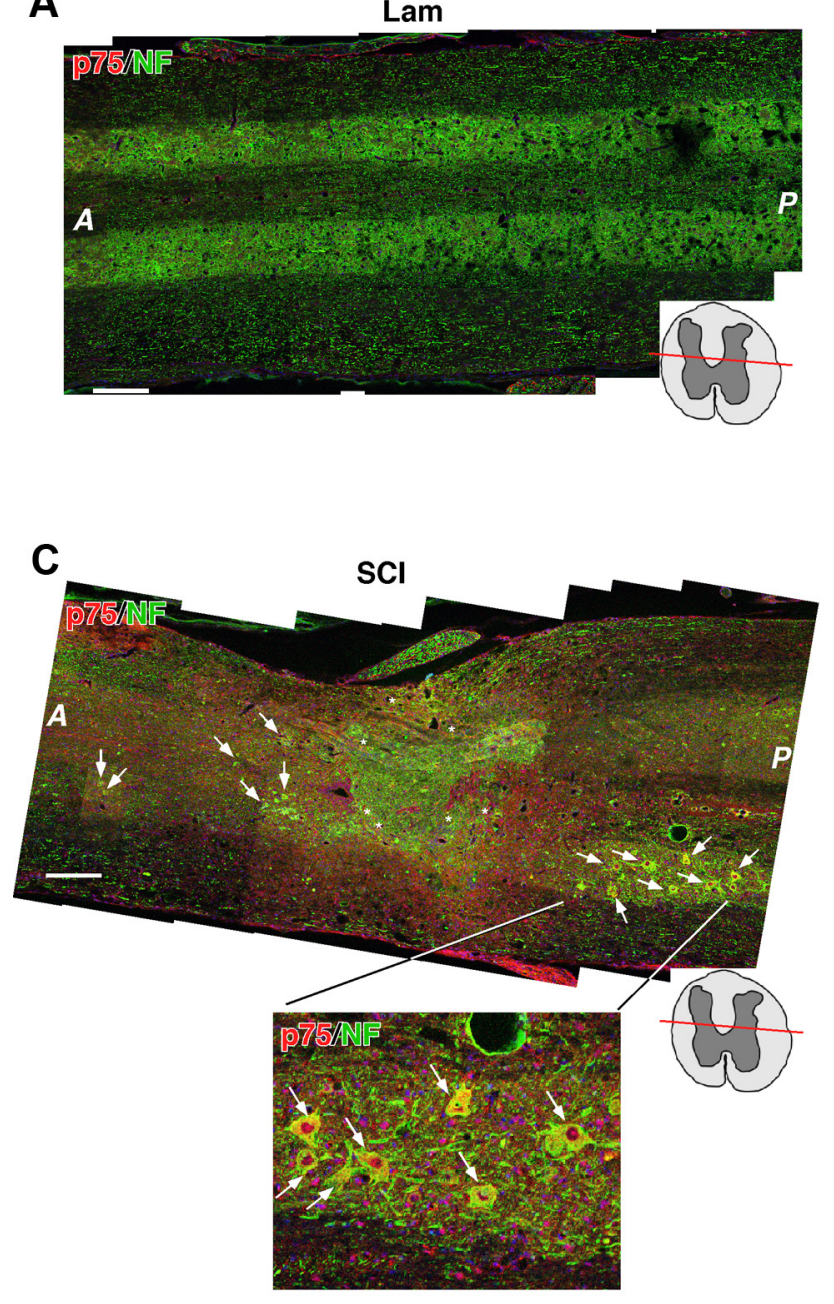

B
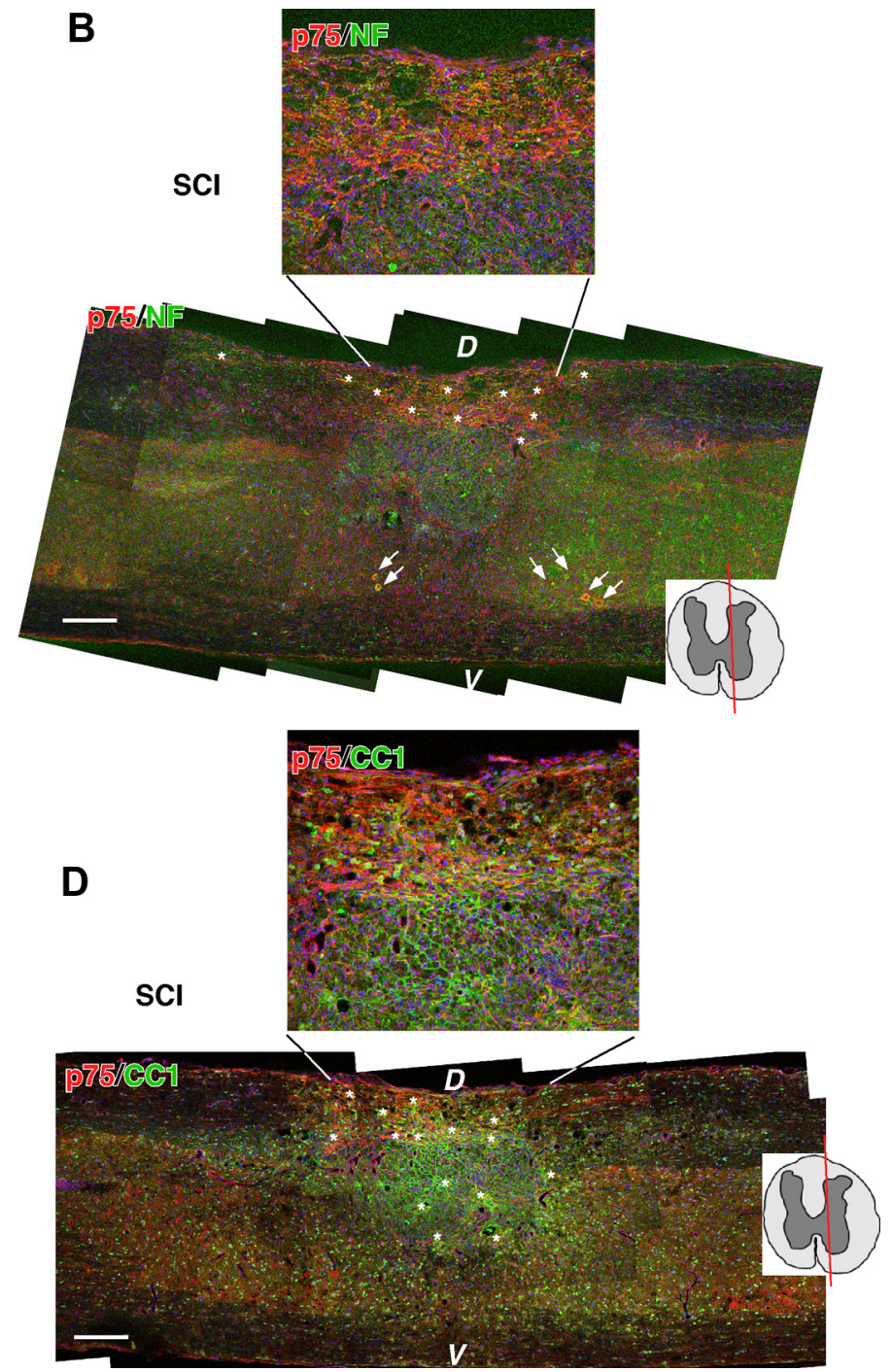

Figure 1. A pattern of p75 expression along the spinal cord axis after contusion injury. A, A horizontal view of p75 expression in laminectomized control spinal cord. Note that there is no $\mathrm{p} 75$ expression. The images were a composite of several images taken along the anterior to posterior axis of the spinal cord as indicated by $A$ and P. Scale bar, $75 \mu \mathrm{m}$. The view plane of the images is also indicated as a red line over a diagram of the spinal cord cross section. C, A horizontal view of 75 expression among $\mathrm{NF}^{+}$neurons along the anterior to posterior axis of the spinal cord at $14 \mathrm{~d}$ after contusion injury. Note that many neurons in the gray matter express 75 (arrows). Scale bar, $75 \mu \mathrm{m}$. A higher magnification view of motor neurons in the gray matter is also shown. $\boldsymbol{B}$, A sagittal view of p75 expression in $\mathrm{NF}^{+}$axons and neurons along the dorsoventral axis of the spinal cord $14 \mathrm{~d}$ after contusion injury. Note that incoming ascending fibers are labeled with p75 in the dorsal column (indicated by stars) as well as neurons in the gray matter (arrows). The image above shows a higher magnification view of the ascending fibers that are positive for p75. D, A sagittal view of p75 expression among $\mathrm{CC}^{+}$oligodendrocytes along the dorsoventral axis (as indicated by $\mathrm{D}$ and $\mathrm{V}$ ) of the spinal cord $14 \mathrm{~d}$ after contusion injury. Note that many yellow oligodendrocytes are found above the lesion area (stars) as well as within the lesion area. The image above shows a higher magnification view of the dorsal column above the lesion area. The experiments were repeated $>3$ times, and representative images are shown.

Basile). Five measurements of the latency of paw withdrawal were obtained, testing each hindpaw alternately, with at least 10-20 min intervals in between. The response time was recorded electronically, and a paw withdrawal threshold was calculated as the mean of five trials.

\section{Tissue processing}

At the end of behavior tests, mice were divided into three groups for the analysis: Group 1 for histology, Group 2 for $1 \mu \mathrm{m}$ thin sections, and Group 3 for biochemical analyses. For the histology group, mice were transcardially perfused with saline, followed by $3 \%$ paraformaldehyde (PFA) in $0.1 \mathrm{~m}$ phosphate buffer (PB), $\mathrm{pH}$ 7.2. The spinal cords were subsequently dissected, postfixed for $2 \mathrm{~h}$ in the same fixative, and transferred to $20 \%$ sucrose in $0.1 \mathrm{~m} \mathrm{~PB}$ overnight at $4^{\circ} \mathrm{C}$. The next day, the cords were divided into $3 \mathrm{~mm}$ segments, and the rostral, caudal, and caudalmost end of the epicenter were marked with a marker. The three tissue blocs were then mounted together with marked sides down in Tissue Tek OCT Compound, fast frozen in a dry ice plus isopentane mixture, and stored at $-80^{\circ} \mathrm{C}$ until sectioning. The cords were sectioned at $20 \mu \mathrm{m}$ thickness and mounted on SuperFrost PLUS microscope slides. Therefore, each slide contained serial $20 \mu \mathrm{m}$ transverse sections that were spaced $100 \mu \mathrm{m}$ apart.

For the thin section group, mice were perfused with 2\% PFA and 2\% glutaraldehyde in $0.1 \mathrm{M}$ cacodylate buffer, $\mathrm{pH}$ 7.2. Spinal cords were dissected, and $3 \mathrm{~mm}$ epicenter segments were collected, then the rostral end of each segment was marked by trimming off its edge. Spinal cords were rinsed in $0.1 \mathrm{M} \mathrm{Na}$ cacodylate buffer, and placed in $1 \%$ osmium and $0.1 \mathrm{~m} \mathrm{Na}$ cacodylate for $1-1.5 \mathrm{~h}$ at room temperature. The tissues were stained en bloc for $1 \mathrm{~h}$ in $2 \%$ uranyl acetate and embedded in Spurr resin after the dehydration procedures. Sections were cut at $1 \mu \mathrm{m}$ from the rostral end and stained for toluidine blue. For the biochemistry group, spinal cords were dissected and quickly frozen in dry ice and 2-methyl butane bath. The frozen tissues were kept at $-80^{\circ} \mathrm{C}$ until ready for protein extraction. 

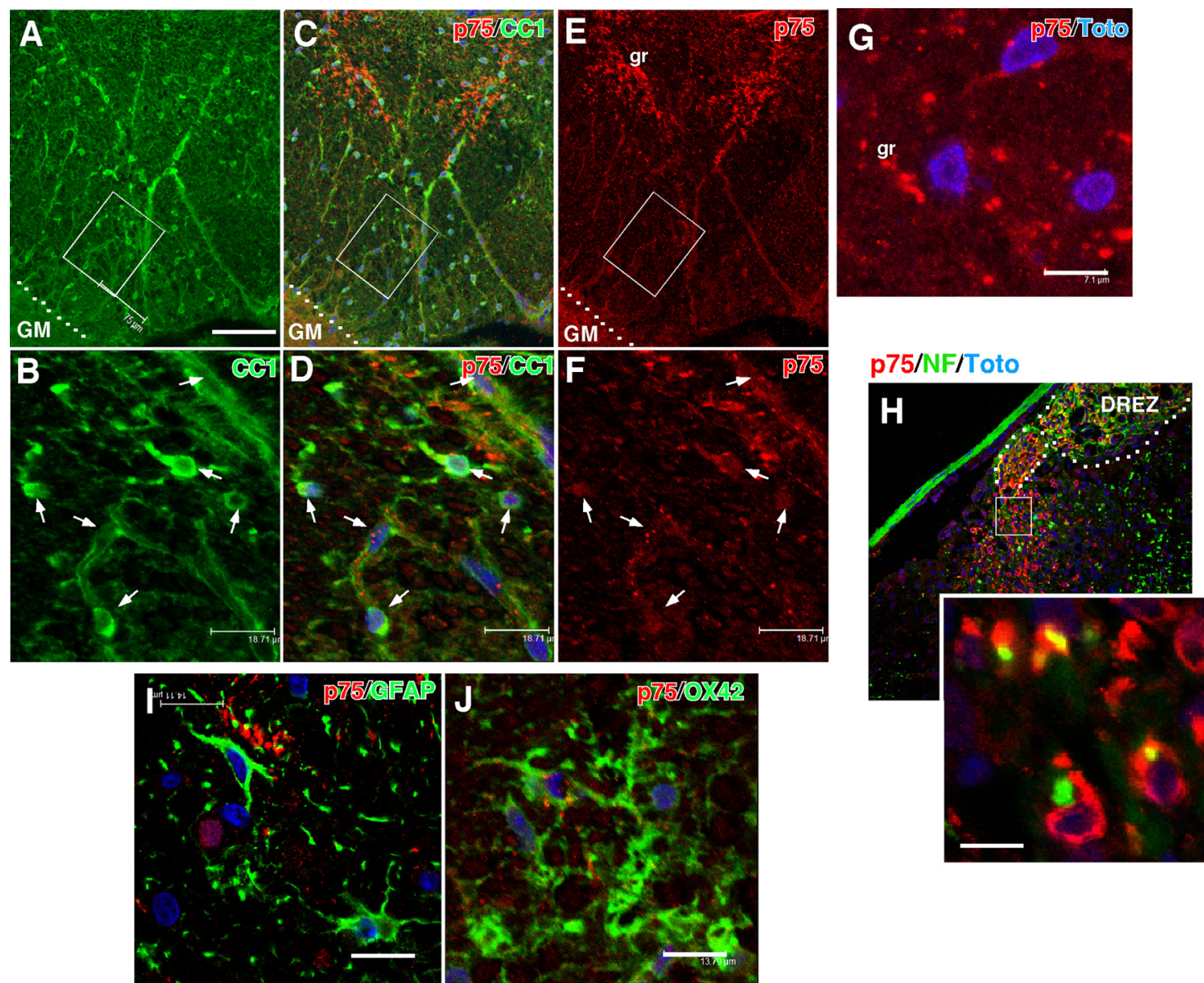

Figure 2. Oligodendrocytes, but not astrocytes or microglia, express p 75 after contusion injury in the spinal cord. $\boldsymbol{A}-\boldsymbol{F}, \mathrm{A}$ coronal view of p 75 expression among $C\left(1^{+}\right.$oligodendrocytes at $14 \mathrm{~d}$ after injury. Boxed areas in $\boldsymbol{A}, \boldsymbol{C}$, and $\boldsymbol{E}$ are shown in a higher magnification in $\boldsymbol{B}, \boldsymbol{D}$, and $\boldsymbol{F}$. Arrows indicate $\mathrm{p}^{+}{ }^{+} \mathrm{CC} 1^{+}$oligodendrocytes. Note that p75 is also expressed in the fasciculus gracilis (gr in $\boldsymbol{E}, \boldsymbol{G}$ ). Scale bars: (for $\boldsymbol{A}, \boldsymbol{C}, \boldsymbol{E}) 75 \mu \mathrm{m}$; (for $\boldsymbol{B}, \boldsymbol{D}, \boldsymbol{F}) 18 \mu \mathrm{m}$; (for $\mathbf{G}) 7 \mu \mathrm{m}$. $\boldsymbol{H}$, Invading Schwann cells in the dorsal root entry zone (DREZ). A boxed area is shown in a high magnification. Scale bar, $7 \mu \mathrm{m}$. Note that p75Schwann cells appear myelinating NFaxons. I, GFAP ${ }^{+}$astrocytes do not express p 75. Note that astrocytic processes are in close contact with p $75^{+}$fibers in the fasciculus gracilis. Scale bar, $14 \mu \mathrm{m} . J, 0 \times 42^{+}$microglia do not express p 75 . Scale bar, $14 \mu \mathrm{m}$. The experiments were repeated $>5$ times, and representative images are shown.

A modified eriochrome cyanine staining for myelin

Every sixth cryostat slide was stained with eriochrome cyanine (EC) to identify myelinated areas according to Kigerl et al. (2007). Briefly, sections were dehydrated in xylene, rehydrated in ethanol series, and stained for 18 min with $10 \% \mathrm{FeCl} 3$ and $0.2 \%$ EC (Sigma) in $0.5 \%$ aqueous $\mathrm{H}_{2} \mathrm{SO}_{4}$. Stained sections were then differentiated for $7 \mathrm{~min}$ in $10 \%$ FeCL3, which was followed by thorough washes in distilled water. Sections were dehydrated through ethanol series and xylene before mounted using Permount.

The total cross-sectional area of the spinal cord and lesion boundary were measured in a blinded manner on digitized images of the cord using a computer-assisted image analysis program (AxioVision 4.7; Zeiss). The digital images of EC-stained sections were obtained using Axiocam and Zeiss Axio Observer Z1. The lesion area was identified by the loss of EC staining as well as severe tissue disruption. The spared white matter was defined as the areas that were stained for EC.

\section{Immunohistochemistry}

Cryostat sections were incubated for $2 \mathrm{~h}$ at room temperature in blocking solution, which contained $0.3 \%$ Triton X-100, 5\% bovine serum albumin (BSA), $5 \%$ goat serum, and $5 \%$ horse serum in TBS. Primary antibodies were applied overnight at room temperature in a solution containing $0.1 \%$ Triton X-100, $1 \%$ BSA, $1 \%$ goat serum, $1 \%$ horse serum, and $0.02 \% \mathrm{Na}$ azide. Antibodies used for immunohistochemistry include p75 (Promega), CC1 (Calbiochem) as a marker for oligodendrocytes, Ox42 (Harlan) for microglia, glial fibrillary acidic protein (GFAP; DAKO) for astrocytes, and Neurofilament (Millipore) for axons and neurons. Slides were counterstained for Toto 3 for nuclei (Invitrogen) and mounted in Vectashield (Vector Laboratories).

\section{Statistical analysis}

Statistical tests were performed using Graphpad Prism2 Software (Instat). Differences between two different dosage groups were evaluated using Student's $t$ test or one-way ANOVA analysis; e.g., BMS scores. Comparison among every dosage group was performed using the Tukey's multiple-comparison test. The probability value for determining statistical significance was set at $p<0.05$. Swimming scores were analyzed with repeated-measures ANOVA, with Tukey's multiplecomparison test at each dosage.

\section{Mitochondrial fractionation of the spinal cord}

Mitochondria were prepared by sucrose density gradients (Marchenko et al., 2000; Liu et al., 2004; Li et al., 2007). Briefly, the $6 \mathrm{~mm}$ spinal cord tissue blocks were homogenized using Dounce homogenizer in 5 vol MS buffer (210 mм mannitol, 70 mм sucrose, 5 mм EDTA, 5 mм Tris, pH 7.5, $10 \mathrm{~mm} \mathrm{NaF}, 0.15 \mu \mathrm{M}$ aprotinin, $22 \mu \mathrm{M}$ leupeptin, $1 \mathrm{~mm}$ sodium vanadate, $1 \mathrm{~mm}$ phenylmethylsulfonyl fluoride). Nuclei were collected after centrifugation for $10 \mathrm{~min}$ at $2500 \mathrm{rpm}$ at $4^{\circ} \mathrm{C}$, and the resulting supernatants were spun at $15,000 \mathrm{rpm}$ for $10 \mathrm{~min}$ at $4^{\circ} \mathrm{C}$. The supernatants were subjected to a $1 \mathrm{~h}$ spin at $100,000 \mathrm{~g}$ to obtain the $\mathrm{S} 100$ fraction, while the crude mitochondrial pellet was resuspended in MS buffer and overlaid onto a step gradient of $1 \mathrm{M}$ and $1.5 \mathrm{M}$ sucrose. The gradient was centrifuged for $30 \mathrm{~min}$ at $85,000 \mathrm{~g}$. The mitochondrial band at the interface was pulled, diluted in $2 \mathrm{vol} \mathrm{MS}$ buffer, and spun for $10 \mathrm{~min}$ at 15,000 rpm. 
Immunoprecipitation/Western analyses

The procedures for Western analyses are as described by (Beattie et al., 2002). Antibodies used include NGF (H-20; Santa Cruz Biotechnology), p75 (Promega), cytochrome $c$ (BD Biosciences), tubulin (Santa Cruz Biotechnology), and JNK3 (Millipore).

JNK3 immunoprecipitation/kinase assays

At the indicated times, the spinal cord lysates were prepared, subjected to immunoprecipitation using JNK3-specific antibody (Millipore). The immune complexes were used in kinase reactions with ${ }^{32} \mathrm{P}-\gamma$-ATP in the presence of GST-c-jun as an exogenous substrate. The kinase reaction was separated by SDS-PAGE and autoradiographed.

\section{Results}

\section{P75 expression pattern in the injured spinal cord}

Before we began testing the effect of LM11A-31, we examined where p75 is expressed after contusion injury in mice. P75 expression was barely detectable in laminectomy controls (Fig. 1A), but in contused specimens at $14 \mathrm{dpi}, \mathrm{p} 75$ was detected most robustly in ascending fibers in the dorsal column (Fig. 1B, stars and inset), and in a majority of motor neurons in the gray matter (Fig. $1 C$, arrows and inset). P75 immunoreactivity was also detected among $\mathrm{CC}^{+}$oligodendrocytes in the dorsal column (Fig. $1 D$, starts and inset). P75 expression in oligodendrocytes was examined more closely in coronal sections after SCI, which demonstrated that p75 is expressed in a majority of oligodendrocytes throughout the dorsal (Fig. $2 A--F$ ) and ventral columns (data not shown). Coronal views of the contused cords revealed that $\mathrm{p} 75^{+}$ascending fibers detected in longitudinal sections in Figure 1 are located in the fasciculus gracilis in the dorsal column (Fig. $2 C, E, G, g r)$. Also detected was strong p75 expression among what appears to be invading Schwann cells in the dorsal root entry zone (Fig. 2H, DREZ marked by white dots). Some of these $\mathrm{p} 75^{+}$Schwann cells appear doughnut shaped, enveloping the $\mathrm{NF}^{+}$fibers (Fig. $2 \mathrm{H}$, inset). We did not detect p75 expression among $\mathrm{Ox} 42^{+}$microglia or $\mathrm{GFAP}^{+}$astrocytes, although these cells appear in close proximity to $\mathrm{p}^{+} 5^{+}$fibers or cells (Fig.2, I, J). These results suggest that p75 expression becomes induced in different cell types after SCI, which include ascending fibers in the fasciculus gracilis, invading Schwann cells as well as motor neurons and oligodendrocytes.

\section{A nonpeptide, small molecule that targets p 75 crosses the blood-spinal cord barrier}

P75 is one of the receptors that play important roles for oligodendrocyte apoptosis after SCI (Beattie et al., 2002). As a way of promoting functional recovery after SCI, we opted to block p75 signaling from the outset by inhibiting or modulating its interaction with a pathological ligand, proNGF, whose expression is dramatically upregulated after SCI (Beattie et al., 2002). From virtual in silico screening of 3D conformer libraries, a small molecule, nonpeptide p75 ligand (LM11A-31, MW 243) was identified to mimic the structure and physical chemistry features of the $\beta$-loop 1 site of NGF, a site known to interact with p75. This compound was shown to be effective in preventing the ability of proNGF to bind p75 and induce death of cultured oligodendrocytes (Massa et al., 2006). LM11A-31 was predicted to have high blood-brain barrier penetration and favorable medicinal properties (Lipinski et al., 2001; Massa et al., 2006), and as predicted it crossed blood-brain barrier efficiently in uninjured mice with a brain half-life of 3-4 h (data not shown). We asked whether LM11A-31 is also able to cross the blood-spinal cord barrier after SCI. For spinal cord bioavailability tests, mice were subjected to contusion injuries, and treated with LM11A-31 at 25 and 100

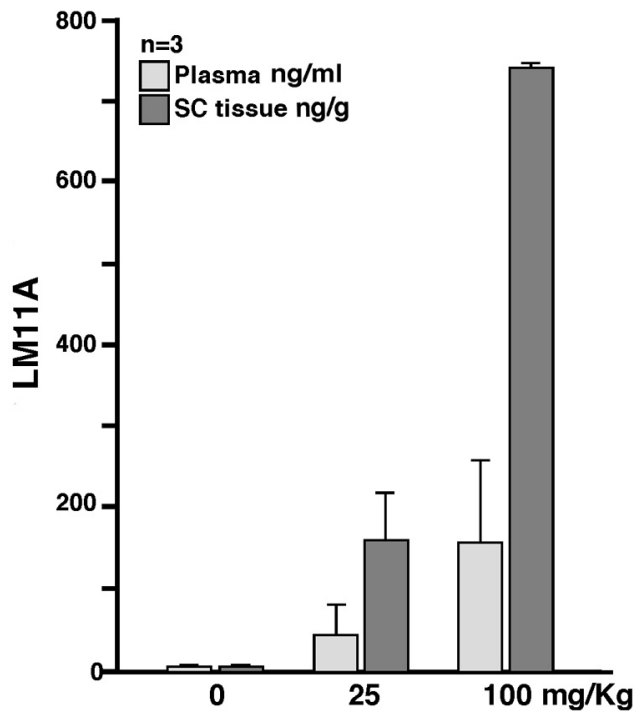

Figure 3. LM11A-31 crosses the blood-spinal cord barrier efficiently after $\mathrm{SCl}$. The amount of LM11A-31 in the plasma and the spinal cord tissues was determined $3 \mathrm{~d}$ after injury by LC-MS/MS. Note that LM11A-31 levels increased in dose-dependent manner both in the plasma and the spinal cord. The tissue/plasma ratio for LM11A-31 was 3.5 and 4.7 at 25 and $100 \mathrm{mg} / \mathrm{kg}$, respectively.

$\mathrm{mg} / \mathrm{kg}$ beginning $4 \mathrm{~h}$ after the injury, then twice a day for $3 \mathrm{~d}$. In general, five doses are considered necessary for a drug to reach a relatively stable pharmacokinetic pattern. Control mice received vehicle treatment. At $1 \mathrm{~h}$ after the last LM11A-31 treatment (after a total of seven doses), blood samples were obtained and mice were perfused with saline to remove intravascular LM11A-31. LM11A-31 levels in plasma and spinal cord extracts were determined by LC-MS/MS analysis by Absorptions Systems. LM11A-31 was detected both in plasma and the spinal cord extract and its levels increased in a dose-dependent manner, reaching $30.5 \mu \mathrm{M}$ in spinal cord extracts (Fig. 3). Most importantly, the ratio of LM11A-31 in the spinal cord vs plasma increased from 3.5 to 4.7 at 25 and $100 \mathrm{mg} / \mathrm{kg}$, respectively (Fig. 3), an exceptionally favorable CNS/plasma value for CNS drug candidates (Abott, 2004; Zheng et al., 2006).

\section{LM11A-31 inhibits proNGF binding to p75 after spinal cord injury}

ProNGF and NGF each bind to p75 through common protein domains including the loop one region while the prodomain of proNGF binds to the sortilin receptor (Nykjaer et al., 2004). In previous work, LM11A-31 competed with proNGF binding to the soluble, extracellular domain of recombinant p75 in vitro with a significant effect starting at a concentration of $2 \mu \mathrm{M}$ (Massa et al., 2006), which is readily attained (Fig. 3). With the full-length p75 expressed in 3T3 cells, preliminary studies have shown that LM11A-31 inhibits proNGF binding at a more physiological concentration of $600 \mathrm{nM}$ at which LM11A-31 was shown to block oligodendrocyte apoptosis in culture (Massa et al., 2006) (data not shown). We therefore tested whether LM11A-31 administration also inhibited proNGF binding to p75 in vivo. For these experiments, lysates were prepared from laminectomy controls as well as injured cords at 1, 7, and $42 \mathrm{dpi}$ and subjected to immunoprecipitation with p75 antibody and blotted with antibody recognizing both pro- and mature NGF. A reciprocal immunoprecipitation was also performed with NGF antibody and blotting for $\mathrm{p} 75$. The amount of proNGF that bound p75 was 


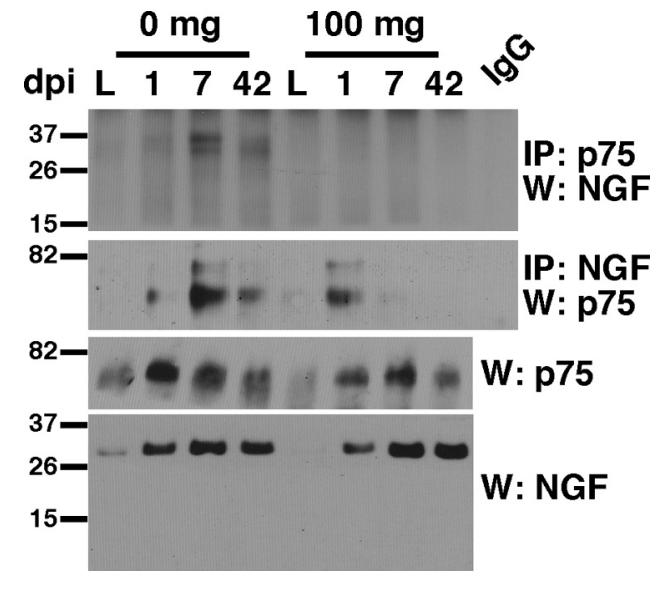

Figure 4. LM11A-31 inhibits proNGF binding to $\mathrm{p} 75$ after SCI. The protein extracts from the spinal cord collected at the indicated times were subjected to immunoprecipitation with $p 75$ or NGF antibodies and the associated NGF or p75 in respective immunoprecipitation reactions were detected in Western blotting. Note that while the extent of increase in total p75 and proNGF levels was similar between 0 and $100 \mathrm{mg} / \mathrm{kg}$ tissues, the interaction between proNGF and $p 75$ was significantly attenuated at $100 \mathrm{mg} / \mathrm{kg}$. The experiments were repeated $>3$ times, and representative blots are shown.

significantly decreased with $100 \mathrm{mg} / \mathrm{Kg}$ LM11A-31 with both immunoprecipitations, while the total amount of proNGF and p75 protein levels was not greatly affected by LM11A-31 (Fig. 4). These results suggest that LM11A-31 is capable of interfering with proNGF binding to $\mathrm{p} 75$ in vivo, consistent with previous in vitro studies (Massa et al., 2006).

\section{There is no weight loss or other obvious adverse effect after LM11A-31 treatment after spinal cord injury}

When tested in uninjured normal adult mice with escalating single doses of LM11A-31 to a maximal dose of $2000 \mathrm{mg} / \mathrm{kg}$, LM11A-31 demonstrated no toxicity based on death, weight loss, changes in behavior, or appetite (data not shown). Although the data suggest that LM11A-31 has no gross toxicity, we examined the possibility that SCI, combined with chronic daily administration for $42 \mathrm{~d}$, might render mice more susceptible to possible LM11A-31-induced toxicity. As a measure of toxicity, we monitored weights for the duration of the study. Among laminectomy control mice, the vehicle group gradually gained weight over the period of $42 \mathrm{~d}$, reaching a 3-5\% increase over the initial weight (Fig. 5A). The weight gain among LM11A-31-treated mice appeared less than the increase from the vehicle-treated control regardless of the dosage, but the difference was not statistically significant (Fig. 5A). Also after SCI, the weight-gain pattern was indistinguishable between the vehicle-treated control group and LM11A-31-treated group regardless of the dosage (Fig. 5B): although injured mice lost up to $10 \%$ of their weight by $10 \mathrm{dpi}$, they began regaining this weight and then reaching their initial weights from before the operations by $20 \mathrm{dpi}$ (Fig. 5B). The incidence of death among injured mice was also very low ( $n=1$ of 200). Collectively, these results suggest that LM11A-31 exhibited no serious toxic effects for the mice even after SCI.

\section{LM11A-31 does not exacerbate pain sensitivity after SCI}

NGF is known to induce neuropathic pain, mainly signaling through TrkA (Lewin et al., 1993; Ro et al., 1999). Although the role of p75 in pain has yet to be fully elucidated, it is possible that LM11A-31 binding to p75 could impact neuropathic pain after SCI by modulating TrkA signaling. While SCI is not a conventional pain model, as part
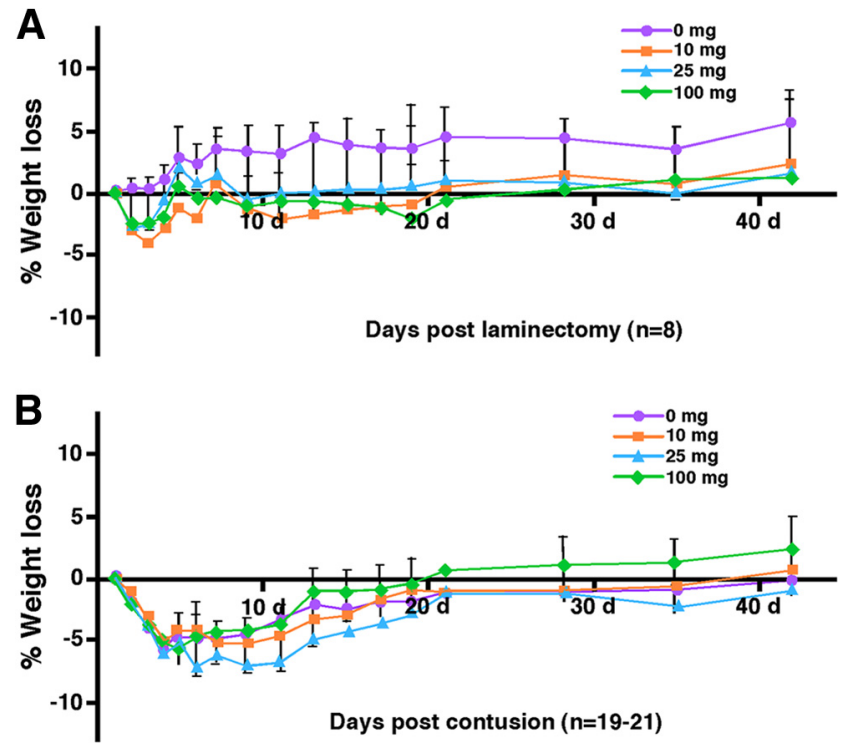

Figure 5. LM11A-31 administration does not affect weight gain after $\mathrm{SCl}$. The change in weight after $\mathrm{SCl}$ is shown over a $42 \mathrm{~d}$ experimental period. $\boldsymbol{A}$, Weight change in laminectomy controls. $\boldsymbol{B}$, Weight change in injured mice. Note that LM11A-31 did not affect weight change at any dosage tested with or without injury; $p$ values were obtained by Student's $t$ tests.

of testing the therapeutic feasibility of LM11A-31, we chose to include two established measures of neuropathic pain, thermal hyperalgesia, and mechanical allodynia as secondary outcome measures, as was done in previous SCI studies (Biernaskie et al., 2007; KarimiAbdolrezaee et al., 2010). The tests were conducted at $42 \mathrm{dpi}$, when mice regained plantar stepping capability.

Our data indicate that LM11A-31 did not increase pain at any dosage, whether mice were subjected to laminectomy or contusion. The only significant difference observed was between the contused and laminectomy groups independently of LM11A-31 administration. In hyperalgesia tests, latency withdrawal time for contused mice was decreased from that of laminectomized mice, suggesting that contusion rendered mice more sensitive to heat (Fig. $6 A ; p \leq$ 0.05 ). This result is in agreement with published data (Bennett and Xie, 1988; Hoschouer et al., 2010). LM11A-31 administration on the other hand had no effect within the laminectomized or contused groups regardless of the dosage. Similar results were obtained in allodynia tests: the contusion group exhibited an increase in both force and time that was required for them to withdraw hindfeet compared with the laminectomized controls, regardless of LM11A-31 (Fig. 6B, $C$; $p \leq 0.05$ ). These data indicate that SCI mice exhibited reduced sensitivity to mechanical stimulus as reported (Bennett and Xie, 1988; Hoschouer et al., 2010). LM11A-31 administration again failed to affect pain response to mechanical stimuli within the laminectomy and contused groups, regardless of the dosage. These results suggest that LM11A-31 does not exacerbate pain either with or without SCI at least in the hindfoot-based pain tests.

LM11A-31 promotes motor function after spinal cord injury To test whether LM11A-31 administration has a beneficial effect on motor function during early stages of recovery after SCI, we performed both weight-bearing and nonweight-bearing behavioral tests using BMS open-field and swim tests, respectively. It should be noted that the BMS scores of all dosage groups throughout the extent of experiments remained at normal scores of 9 among laminectomy control groups, similar to baseline before sham injury (data not shown), in agreement with our toxicity results. 
A

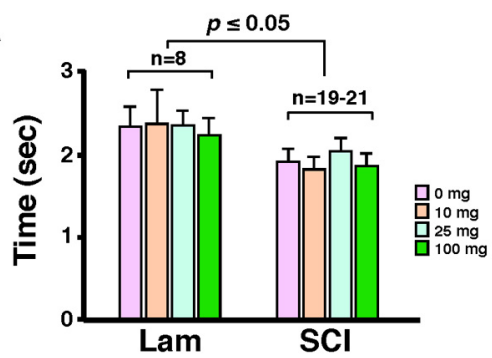

B

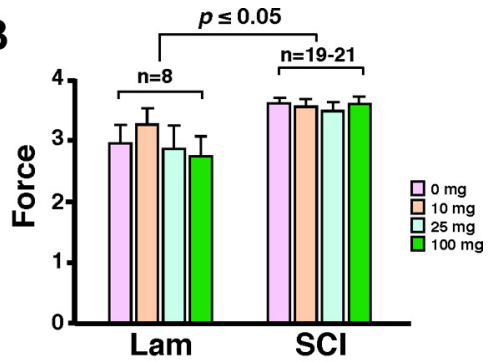

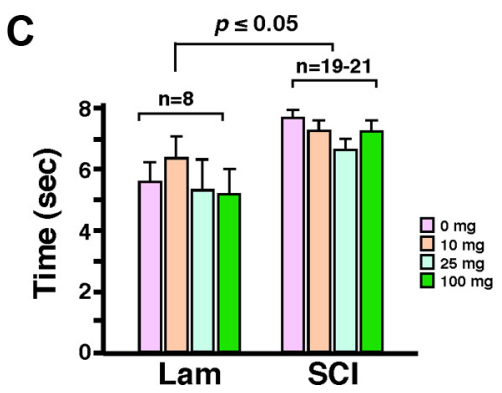

Figure 6. LM11A-31 does not exacerbate pain sensitivity after SCI. A, Results from thermal hyperalgesia tests on the hindpaws of laminectomy controls and contused mice at $42 \mathrm{dpi}$. SCI-induced thermal hyperalgesia; Contused mice withdrew hindpaws faster than laminectomy controls regardless of LM11A-31 dosage ( $p \leq 0.05)$. LM11A-31 administration, on the other hand, had no effect on thermal hyperalgesia at any dosage whether mice were contused or not. $\boldsymbol{B}, \boldsymbol{C}$, Force and time measurements from mechanical allodynia tests on the hindpaws at $42 \mathrm{dpi}$. It took more force and time for contused mice to withdraw hindpaws than laminectomy controls regardless of LM11A-31 dosage ( $p \leq 0.05$ ). LM11A-31 administration, in contrast, had no effect on mechanical allodynia at any dosage whether mice were contused or not; $p$ values were obtained by one-way ANOVA tests and comparisons between dosages were analyzed using Tukey's multiple-comparison test.

At $50 \mathrm{kdyne}$ force, all injured animals regardless of treatment developed complete paraplegia the day after the contusion, corresponding to a BMS score of $0-1$. The vehicle-treated control mice began demonstrating improvements in motor function by 2-3 dpi, and gained plantar stepping by 10 dpi with BMS scores at 3.9-4.6 on average, which persisted until observations were discontinued at 42 dpi (Fig. 7A). A BMS score of 4-5 signifies frequent plantar stepping without much coordination (Basso et al., 2006). The mice treated with LM11A-31 at 10 and $25 \mathrm{mg} / \mathrm{kg}$ behaved similarly to vehicle-treated animals, without demonstrating any dose-dependent increase. At $100 \mathrm{mg} / \mathrm{kg}$, however, an improvement was evident, reaching a BMS score of 6.1 and 7.1 at 21 and $35 \mathrm{dpi}$, respectively, which persisted until 42 dpi (Fig. 7A). A BMS score of 7 signifies most coordination while stepping, although trunk stability and normal paw position placement are still compromised. It should be noted that even when subscores were analyzed for more detailed behaviors, improvement was observed only at $100 \mathrm{mg} / \mathrm{kg}$ (Fig. $7 B$ ). We interpret these results as suggesting that LM11A-31 administration improved motor behavior, especially overall coordination after SCI at 100 $\mathrm{mg} / \mathrm{kg}$.
A

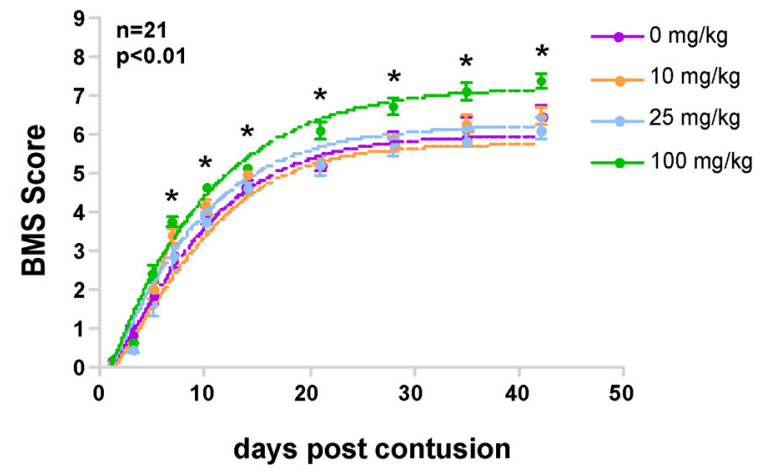

B

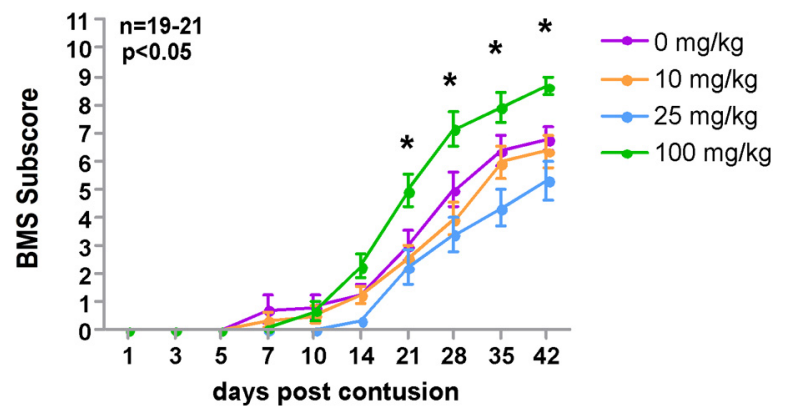

Figure 7. LM11A-31 promotes motor function in open-field behavioral tests at $100 \mathrm{mg} / \mathrm{kg}$. A, LM11A-31 administration at $100 \mathrm{mg} / \mathrm{kg}$ promotes motor function when tested by BMS tests. $\boldsymbol{B}$, In BMS subscore analysis, LM11A-31 was effective only at $100 \mathrm{mg} / \mathrm{kg} ; p$ values were obtained by one-way ANOVA with Tukey's multiple-comparison test at each dosage.

\section{LM11A-31 improves coordination during swimming at $100 \mathrm{mg} / \mathrm{kg}$}

A limitation in the BMS testing is that it relies on the ability to bear weight, and it focuses on movements that are controlled by reflex pathways in the spinal cord (Smith et al., 2006). It is possible that LM11A-31 may influence locomotion that is independent of weight-bearing ability. We therefore subjected mice to swimming tests at 42 dpi according to (Gullo et al., 2008). In addition to obviating the need to bear weight, swim tests allow assessment of a phasic relationship between right and left alternation of limb flexion and extension as in walking, which relies on the integrity of the descending motor tract in the cord (Smith et al., 2006). The swim test was adapted for mice from rat (Gullo et al., 2008) by including four of the five independent parameters for overall scoring: forelimb usage, velocity, hindpaw position, and hindlimb coordination were included but not tail movement.

Representative consecutive still images of swimming are shown in Figure $8 A$, which illustrates phasic motion as mice swam across the swim tank from right to left over time. The laminectomized mouse exhibited normal alternate hindlimb kicking motion as indicated by red and blue dots that mark the position of hindfeet (Fig. 8A, top row). The mouse that had received the vehicle treatment after contusion injury, on the other hand, failed to move the hindfeet in typical phasic motion (Fig. 8, middle row), while the mouse with $100 \mathrm{mg} / \mathrm{kg}$ LM11A-31 after contusion injury behaved similarly to the laminectomy control, exhibiting alternate hindlimb kicking motion (Fig. $8 A$, bottom row). When the swim behavior was quantified as cumulative 
A
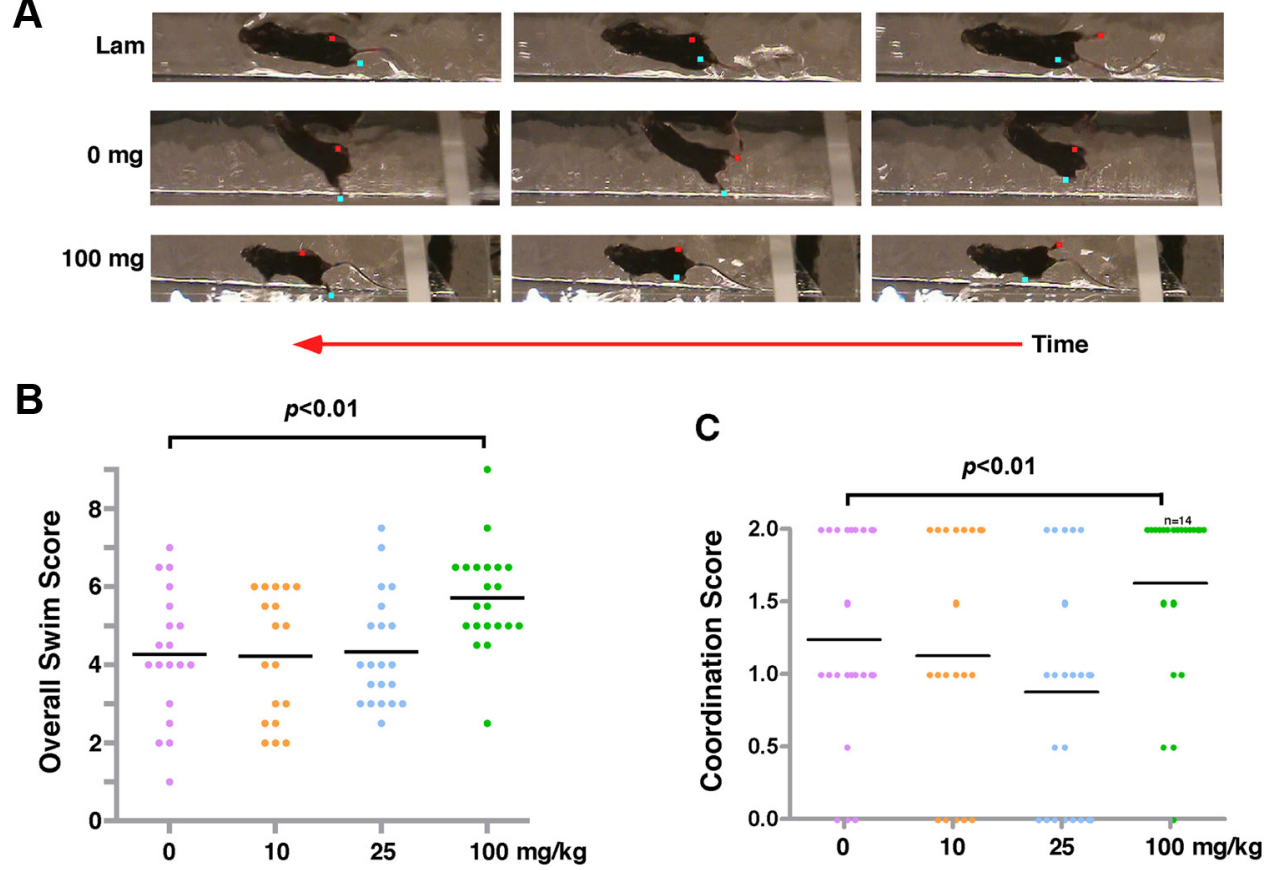

Figure 8. LM11A-31 promotes motor coordination in swim tests at $100 \mathrm{mg} / \mathrm{kg}$. $A$, Representative still-frame images showing mouse swimming across the swim tank over time, from right to left. The first row comprises consecutive images of a laminectomy control and the second and third rows are consecutive images of contused mice that received 0 and $100 \mathrm{mg} / \mathrm{kg} \mathrm{LM} 11 \mathrm{~A}-31$, respectively. To highlight the kicking motion of hindpaws as the mice were swimming, left and right feet were marked with blue and red dots, respectively. Note that the mouse treated with $100 \mathrm{mg} / \mathrm{kg} \mathrm{LM} 11 \mathrm{~A}-31$ exhibited alternate kicking similar to the laminectomy control, while the one treated with $0 \mathrm{mg} / \mathrm{kg}$ produced random motion of its hindlimbs. The lack of coordinated, alternate kicking indicates impairment in hindlimb recovery. $\boldsymbol{B}$, Overall swim scores indicate that LM11A-31 was effective in promoting motor function at $100 \mathrm{mg} / \mathrm{kg}$. Bars indicate median scores, while dots represent the scores of individual mice. C, The improvement in overall scores at $100 \mathrm{mg} / \mathrm{kg}$ was attributed to improved coordination. Bar indicates median scores, while dots represent the scores of individual mice; $p$ values were obtained by repeated-measures ANOVA with Tukey's multiple-comparison test at each dosage.

A

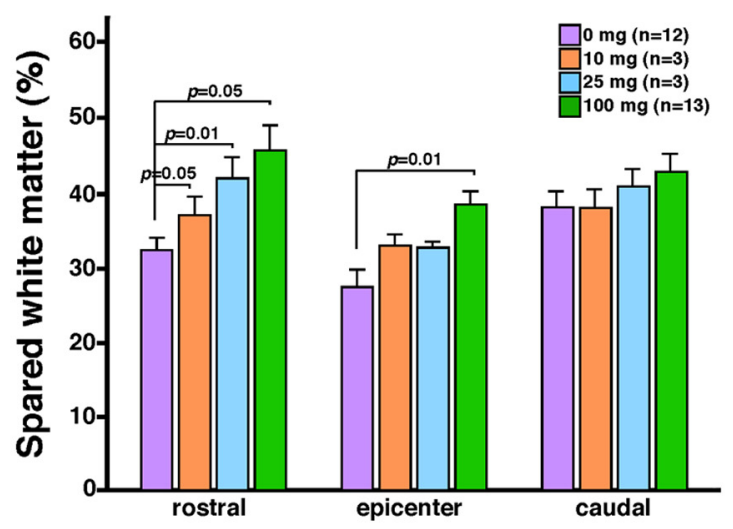

B

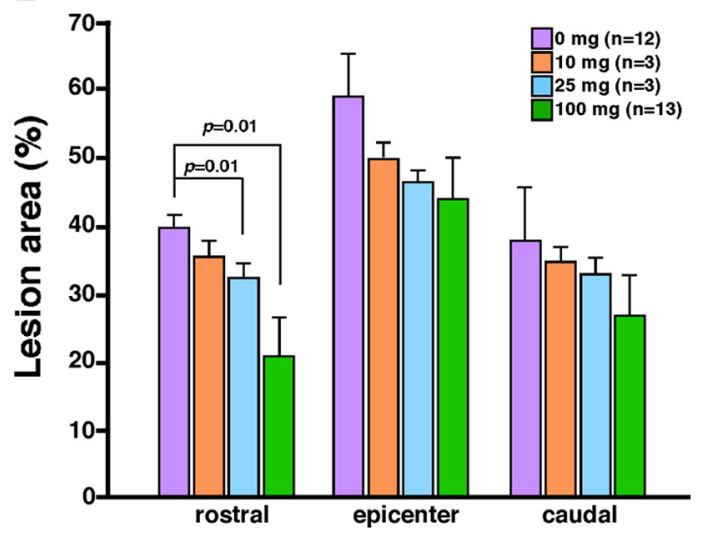

C

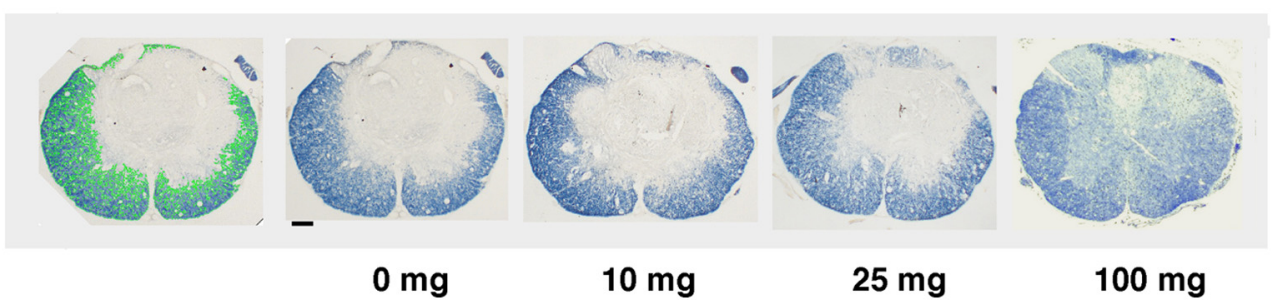

Figure 9. LM11A-31 promotes myelin sparing in a dose-dependent manner. $\boldsymbol{A}$, The extent of spared myelin was quantified by measuring EC-stained areas within $1 \mathrm{~mm}$ rostral, epicenter, and caudal regions, and expressed as the percentage to total spinal cord areas in each section. Note that myelin sparing increased in a dose-dependent manner in the rostral region, while it increased significantly only at $100 \mathrm{mg} / \mathrm{kg}$ in the epicenter region. $\boldsymbol{B}$, The lesion area was also reduced in a dose-dependent manner at $25 \mathrm{and} 100 \mathrm{mg} / \mathrm{kg}$ within the rostral region; $p$ values were obtained by Student's $t$ tests. C, Representative images of EC-stained spinal cord sections at 150-200 $\mu \mathrm{m}$ from the lesion epicenter. Dose-dependency is most evident in the dorsal column. The far left image taken from Axiovision 4.7 illustrates the area demarcated in green lines was quantified as myelinated. Scale bar, $75 \mu \mathrm{m}$. 
A

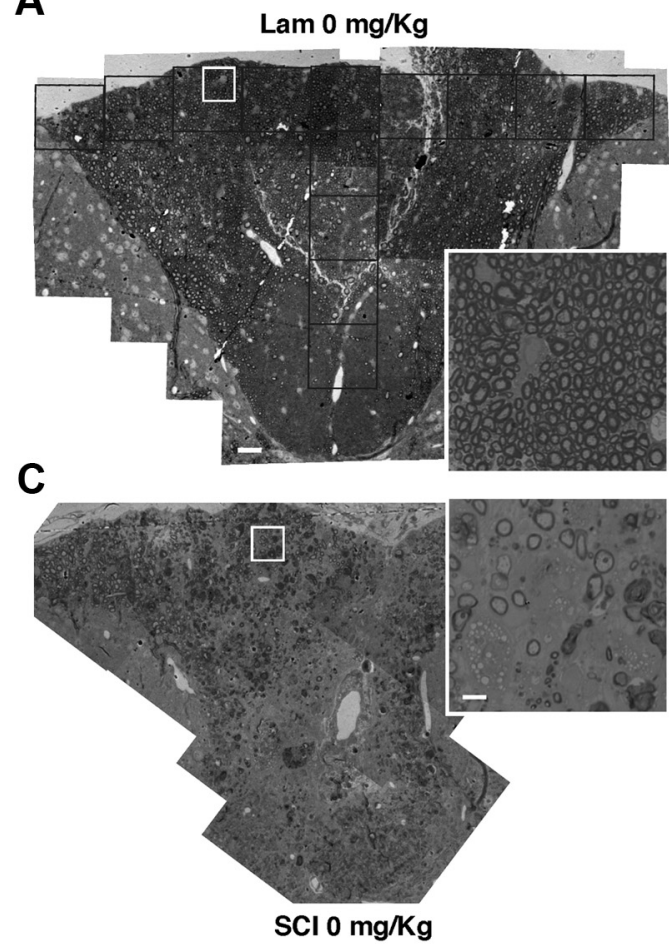

B
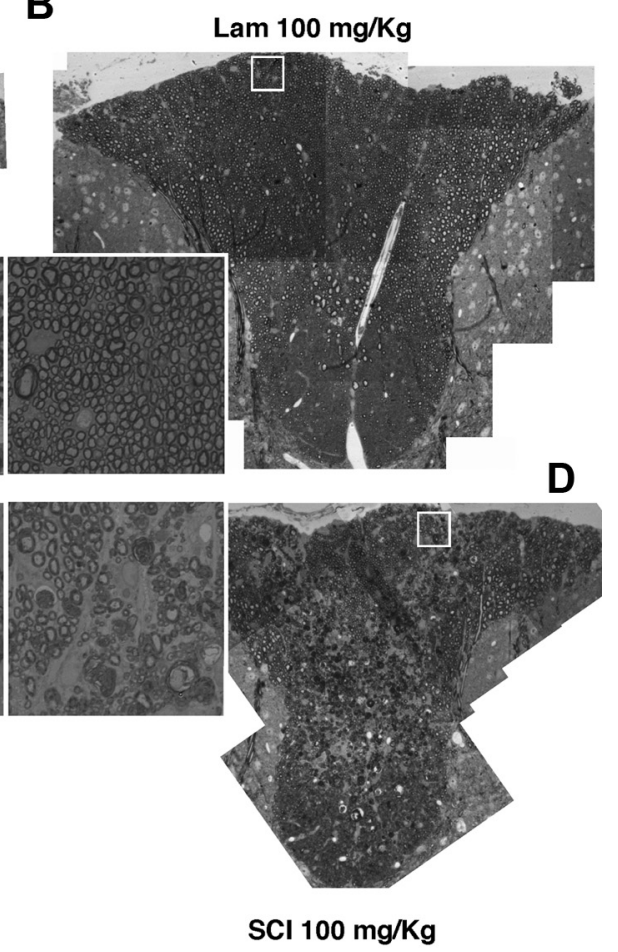

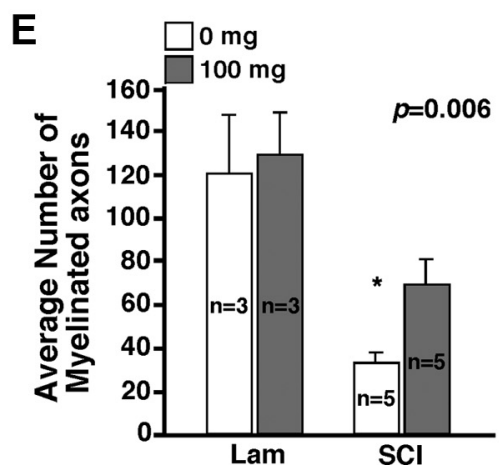

Figure 10. LM11A-31 increased the number of myelinated axons by twofold at $100 \mathrm{mg} / \mathrm{kg} . A-D$, Representative images of the myelin profile in the dorsal column after toluidine blue staining. The boxed areas from the most dorsal regions in the midline in $\boldsymbol{A}-\boldsymbol{D}$ are also shown at the center (white-lined box). The black-lined boxes in $\boldsymbol{A}$ indicate the areas selected for quantification of myelinated axons. $\boldsymbol{E}$, The average number of myelinated axons in the box increased by twofold with $100 \mathrm{mg} / \mathrm{kg}$ LM11A-31 compared with that with $0 \mathrm{mg} / \mathrm{kg}$ samples; $p$ values were obtained by Student's $t$ tests.

scores, the overall improvement at $100 \mathrm{mg} / \mathrm{kg}$ was evident (Fig. $8 B$ ); the average was 5.7 at $100 \mathrm{mg} / \mathrm{kg}$ with the values ranging from 2.5 to 9.0 , while it was 4.2 with values ranging from 0.0 to 7.5 for the other treatment groups. As with BMS testing, the improvement was again observed only at $100 \mathrm{mg} / \mathrm{kg}$. When individual parameters were independently analyzed, this improvement was mainly attributable to improvement in hindlimb coordination (Fig. $8 \mathrm{C}$ ): the average score for hindlimb coordination for the $100 \mathrm{mg} / \mathrm{kg}$ group was 1.6 , with $67 \%$ exhibiting a perfect coordination score of 2.0. The proportion of the mice with 2.0 scores in other groups was 38,37 , and $24 \%$ for the vehicle, 10 , and $25 \mathrm{mg} / \mathrm{kg}$, respectively. These results suggest that LM11A-31 promotes motor coordination in nonweight-bearing swim tests as it did in weight-bearing open-field tests at $100 \mathrm{mg} / \mathrm{kg}$.

\section{LM11A-31 increased myelin sparing in a dose-dependent manner}

LM11A-31 failed to demonstrate a linear dose response in behavioral assays, although there was a clear dose-dependent increase in the amount of LM11A-31 detected in the spinal cord (Fig. 3). Since behavioral assays do not necessarily produce linear outcomes, we decided to determine whether there is a detectable linear dose response in the extent of myelin spared. Myelin loss and spared white matter were assessed at 42 dpi with EC staining of serial cross sections of the spinal cord according to (Kigerl et al., 2007), and the EC-stained areas were quantified using AxioVision 4.7. An example of the area quantified is shown (Fig. 9C, green area). When quantification was divided into $3 \mathrm{~mm}$ rostral, epicenter, and caudal segments, we found that little damage was noticeable in the rostral and caudal $3 \mathrm{~mm}$ segments at $50 \mathrm{kdyne}$ (data not shown). We therefore compared the lesion area and myelin-sparing values among the three $1 \mathrm{~mm}$ segments within the $3 \mathrm{~mm}$ epicenter.

The extent of spared myelin increased in a dose-dependent manner in the rostral region. The increase was statistically significant at every dosage, with $100 \mathrm{mg} / \mathrm{kg}$ exhibiting the greatest increase, $40 \%$ above the value from the vehicle control (Fig. $9 A$ ). Representative images of EC-stained sections taken from rostral 
150-200 $\mu \mathrm{m}$ away from the lesion epicenter of $0,10,25$, and $100 \mathrm{mg} / \mathrm{kg}$ groups are shown in Figure 9 C. Also at the lesion epicenter, an increase in myelin sparing was observed with increasing dosage, but only the increase at $100 \mathrm{mg} / \mathrm{kg}$ was statistically significant compared with that in the vehicle control (Fig. 9A). The extent of myelin sparing correlated with a reduction in lesion area in the rostral region, which also demonstrated a similar dose-dependent response, with $100 \mathrm{mg} / \mathrm{kg}$ exhibiting the biggest reduction of $50 \%$ (Fig. 9B). At the epicenter, lesion area was reduced by increasing the dose of LM11A-31, but none was statistically significant (Fig. 9B). These results are in line with dose-dependent increase that was observed with LM11A-31 in the tissue and plasma. It should be pointed out that our results agree with a previous report where myelin loss was most noticeable in the rostral and epicenter regions in rats as well as monkeys after SCI (Crowe et al., 1997).

We next investigated whether the increased myelin sparing correlated with an increase in the number of myelinated axons using $1 \mu \mathrm{m}$ toluidine blue-stained sections from 0 and $100 \mathrm{mg} / \mathrm{kg}$ samples at 42 dpi. Representative composite images of the dorsal column as well as high-magnification images are shown in Figure $10 A-D$. These images were taken from 140 to $180 \mu \mathrm{m}$ away from the injury epicenter. For quantification, we focused on the dorsal column by drawing rows of boxes vertically along the midline and horizontally across the farthest dorsal area, and counted the number of myelinated axons within each box (Fig. 10A, black lined boxes). The average number of myelinated axons in the boxed area from laminectomy controls was similar between 0 and $100 \mathrm{mg} / \mathrm{kg}$ at 120.6 and 130.3 , respectively, but it increased by twofold with $100 \mathrm{mg} / \mathrm{kg}$ LM11A-31 compared with the vehicle control after SCI: the average was 34.1 and 70.4 for 0 and 100 $\mathrm{mg} / \mathrm{kg}$, respectively (Fig. 10E).

To determine whether increased myelin sparing observed with EC and toluidine blue staining was associated with increased survival of oligodendrocytes, we quantified $\mathrm{CC}^{+}{ }^{+}$cells in the white matter of the cord within the $3 \mathrm{~mm}$ long epicenter regions at $42 \mathrm{dpi}$. Representative images of $\mathrm{CC}^{+}{ }^{+}$cells that were quantified are shown in Figure $11 B$. The number of $\mathrm{CC} 1{ }^{+}$oligodendrocytes increased by 54 and $80 \%$ in the rostral and epicenter $1 \mathrm{~mm}$ regions, respectively, in mice that were treated with $100 \mathrm{mg} / \mathrm{kg}$ LM11A-31 (Fig. 11A,B). Together, these results suggest that LM11A-31 administration increased oligodendrocyte survival, which contributed to the increased myelin sparing and an increase in the number of myelinated axons.

Improved oligodendrocyte survival is likely to have a secondary effect on axon regeneration and/or glial scar formation. As a way of addressing the question, we subjected protein lysates to Western blotting for NF and chondroitin sulfate proteoglycan (CSPG). LM11A-31 administration did not have much effect on changes in NF and CSPG protein levels after SCI either with or without LM11A-31 at $100 \mathrm{mg} / \mathrm{kg}$ (Fig. 12A). The pattern of little change in NF is also evident with NF immunohistochemistry of the cord on coronal planes (Fig. 12B). Although more careful studies are necessary for firm conclusions, these results may suggest that LM11A-31 administration did not affect axonal re/degeneration and glial scar formation greatly.

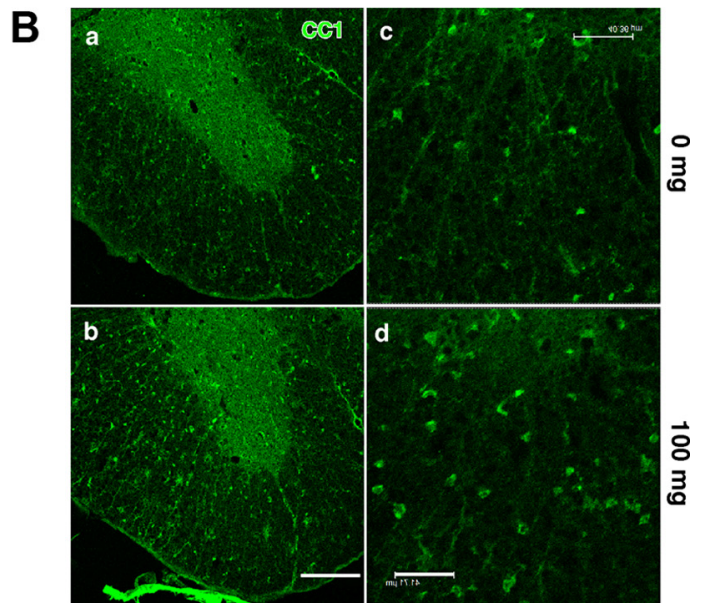

\section{홍 \\ .}

Figure 11. $\mathrm{LM} 11 \mathrm{~A}-31$ promotes the number of surviving oligodendrocytes. $\boldsymbol{A}$, The number of $\mathrm{CC} 1^{+}$oligodendrocytes increased within the rostral and the injury epicenter regions with LM11A-31 at $100 \mathrm{mg} / \mathrm{kg} .{ }^{*} p<0.05,{ }^{* *} p<0.01$ based on Student's $t$ tests. $1^{+}$oligodendrocytes in the ventral white matter.

\section{LM11A-31 inhibits p75-mediated JNK3 activation after SCI}

It is possible that the effect that was observed with LM11A-31 is due to significant off-target effects. One of the most sensitive ways to determine whether LM11A-31 has off-target effects is measuring the extent of JNK3 activation after SCI. Although JNK3 was activated in both neurons and oligodendrocytes after SCI, it was the extent of oligodendrocyte but not neuronal apoptosis that was regulated by JNK3 (Li et al., 2007). Regarding the mechanisms, we hypothesized that $\mathrm{p} 75$ is responsible for activating JNK3 among neurons, since p75 was a receptor involved in eliciting an apoptotic response in oligodendrocytes after SCI (Beattie et al., 2002). Indeed, we found that LM11A-31 administration resulted in a significant reduction in JNK3 activity: JNK3 activity was attenuated by 36 and $42 \%$ at 1 and 7 dpi, respectively, when LM11A-31 was administered at $100 \mathrm{mg} / \mathrm{kg}$ compared with that in vehicle controls (Fig. 13A,B). In line with the effect on JNK3 activity, cytochrome $c$ levels were also significantly reduced in the S100 fraction of spinal cords treated with LM11A-31, while they remained elevated in the mitochondria fraction up to $42 \mathrm{dpi}$ in LM11A-31 group (Fig. 13C,D), indicating that LM11A-31 inhibits mitochondrial release of cytochrome $c$, a hallmark of apoptosis (Liu et al., 1996). We have previously reported that JNK3 disrupts mitochondrial homeostasis, thereby triggering cytochrome $c$ release from the mitochondria (Li et al., 2007).

To next test whether the effect of LM11A-31 on JNK3 activity was via blocking p75 signaling, $\mathrm{p} 75^{-1-}$ mice were subjected to SCI and administered $100 \mathrm{mg} / \mathrm{kg}$ LM11A-31 or the vehicle. Comparison of the overall JNK3 activity between the wild-type and p $75^{-1-}$ mice after vehicle treatment revealed that $\mathrm{p} 75$ is indeed a receptor involved in activating JNK3 after SCI: while JNK3 activity was increased by 2.3 -fold in the wild-type at $1 \mathrm{dpi}$, its increase reached only 1.3 -fold in $75^{-1-}$ mice (compare Fig. 13B,F). LM11A-31 treatment in p $75^{-/-}$mice, on the other hand, failed to reduce the extent of JNK3 activity further, in marked contrast to its ability to inhibit JNK3 activation at 1 and 7 dpi by $~ 50 \%$ in the wild-type mice (Fig. 13E,F). These results suggest that LM11A-31 indeed targets p75 as was originally designed, inhibiting its apoptotic action, and thereby promoting oligodendrocyte survival.

\section{Discussion}

Here, we report a noninvasive strategy for improving functional recovery by targeting to promote oligodendrocyte survival and myelin 
A

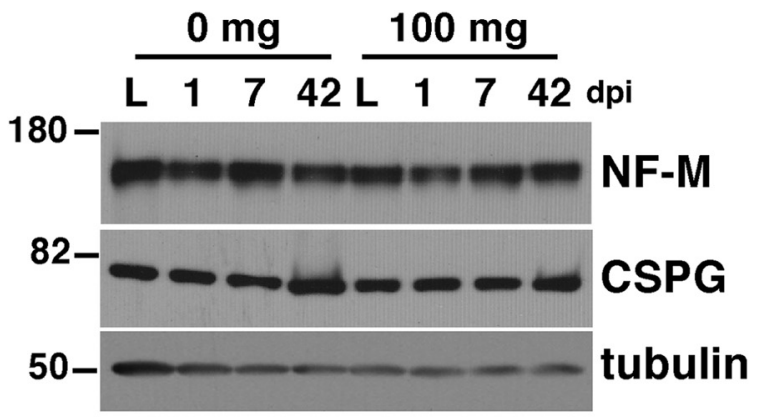

B

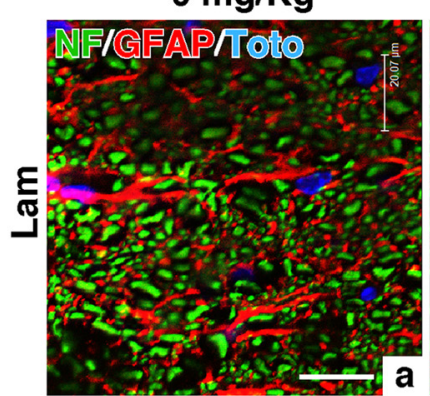

$0 \mathrm{mg} / \mathrm{Kg}$
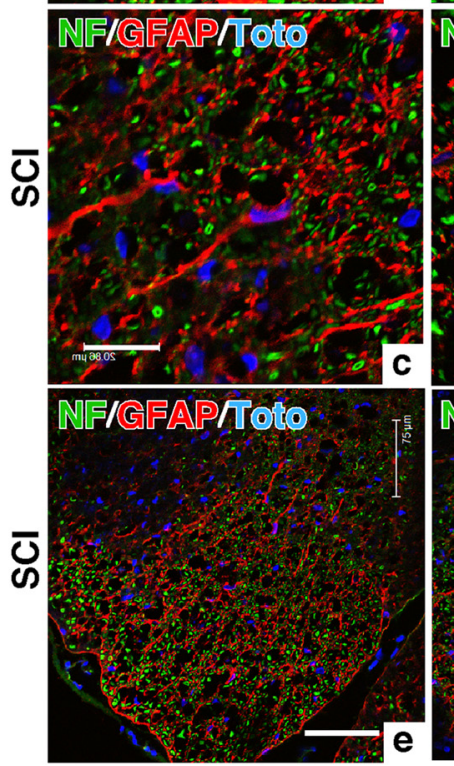

Figure 12. LM11A-31 did not change NF and CSPG protein levels. $\boldsymbol{A}$, NF and CSPG protein levels were not greatly affected by LM11A-31. Tubulin, a loading control, is also shown. $\boldsymbol{B}$, Representative images from NF and GFAP immunohistochemistry at $42 \mathrm{dpi}$. The images in $\boldsymbol{a}$ and $f$ were taken from the ventral regions of the laminectomy controls with the vehicle or LM11A-31 at $100 \mathrm{mg} / \mathrm{kg}$. Scale bars, (for $\boldsymbol{a}-\boldsymbol{d}$ ) $20 \mu \mathrm{m}$; (for $\boldsymbol{e}, \boldsymbol{f}) 75 \mu \mathrm{m}$. The experiments were repeated $>4$ times, and representative images are shown.

sparing after SCI without any exacerbated pain or weight loss. LM11A-31 was highly efficient in crossing the blood-spinal cord at a tissue/plasma ratio of $3-5$, and inhibited proNGF binding to p75 in vivo, resulting in a twofold increase in the number of surviving oligodendrocytes and myelinated axons. Functionally, LM11A-31 improved motor coordination both in weightbearing open-field (BMS) and nonweight-bearing swim tests at $100 \mathrm{mg} / \mathrm{kg}$. These findings illustrate that targeting p75 can be a novel, noninvasive strategy for achieving effective SCI therapy. As far as we are aware, this is the first time that a noninvasive therapeutic measure that was designed based on mechanistic data proved to improve both motor function and morphological endpoints.
The extent of improvement in BMS scores was 2.5 at 100 $\mathrm{mg} / \mathrm{kg}$ LM11A-31 compared with vehicle control (from 4.6 vs 7.1). This is comparable to other studies that aimed at oligodendrocytes or myelin as a means for SCI therapy, although all used rats rather than mice, using BBB and not BMS scoring (Pearse et al., 2004; Cao et al., 2005; Hofstetter et al., 2005; Keirstead et al., 2005; Karimi-Abdolrezaee et al., 2006; Biernaskie et al., 2007; Yune et al., 2007; Cao et al., 2010). It should be emphasized that in contrast to most of these studies that relied on combinatory approaches, some of which were highly invasive involving cell transplantation, oral administration of a single reagent, LM11A31 , produced a comparable level of functional recovery. The other single reagent study with $90 \mathrm{mg} / \mathrm{kg}$ minocycline administration was also effective in promoting functional recovery (Yune et al., 2007), but others failed to reproduce the results (Pinzon et al., 2008; Saganov á et al., 2008; Kwon et al., 2011). The results with LM11A-31 await validation tests by others. Still, we construe our data to be encouraging that myelin sparing increased in a linear dose-dependent manner, although the behavior tests did not demonstrate linear-dose dependency.

Although LM11A-31 did not show linear dose dependency in behavioral assays, it demonstrated a clear, progressing dose response in the extent of myelin sparing. These results suggest that behavioral improvement that was observed at $100 \mathrm{mg} / \mathrm{kg}$ is likely due to blocking p75 binding to proNGF and modulating p75 signaling. Why, then, was a dose-dependent response not observed in behavioral assays? Obviously, we cannot rule out off-target effects contributing to the overall improvement that we have observed, although our JNK3 activity data from p75-null mice suggest that LM11A-31 targets p75. We, however, believe that a most likely reason is that we assessed relatively gross behaviors, that is, the behavior tests that we used were not designed to detect minute changes in certain behavior that might have resulted from LM11A-31 at 10 and $25 \mathrm{mg} / \mathrm{kg}$. This is likely, especially considering the fact that motor behaviors are complex in nature, not to mention that they do not necessarily improve in a linear fashion, although we do assign numerical values to different gradations of behavior outcomes. Alternatively, LM11A-31 becomes metabolized so rapidly in the nervous system that its total exposure per dose to its target at 10 and $25 \mathrm{mg} / \mathrm{kg}$ is insufficient to reach the threshold for functional effects. Indeed, the ratio of LM11A-31 in the brain versus plasma increased from 3.5 to 4.7 at 25 and $100 \mathrm{mg} / \mathrm{kg}$, respectively (Fig. 3), suggesting that more LM11A-31 was retained in the spinal cord tissue at $100 \mathrm{mg} / \mathrm{kg}$ than at $25 \mathrm{mg} / \mathrm{kg}$. It should be emphasized, however, that ratios of 3.5-4.7 are considered exceptionally favorable for a CNS drug candidate (Abott, 2004; Zheng et al., 2006). It will be of interest to test whether more frequent administration of LM11A-31 than twice daily schedule will result in further improvement in motor behaviors, considering its relatively short half-life of 3-4 h. A third possibility is that a critical threshold exists in the proportion of axons that must be myelinated before a successful functional recovery is detectable in the currently available behavioral assays. If this is the case, we surmise that the threshold resides at $\sim 50 \%$ of total axons based on our quantification of myelinated axons at $100 \mathrm{mg} / \mathrm{kg}$ (Fig. 10E).

It should be noted that our analysis does not distinguish between whether LM11A-31 was having an effect on demyelination or remyelination. We nonetheless believe its effect is most likely to be on demyelination rather than remyelination. The reasons are severalfold: (1) a reduction in p75-proNGF interaction was evident from $1 \mathrm{dpi}$, suggesting that p75-dependent JNK3 activation should already have become reduced at this time, which was indeed validated in JNK3 activity assays; (2) the myelin sheath 
does not appear particularly thinner with LM11A-31 administration than in the laminectomy controls, although electron microscopic analyses will be necessary for quantifiable comparisons; and (3) oligodendrocyte apoptosis was significantly reduced beginning at $4 \mathrm{~h}$ after injury in JNK3-null mice (Li et al., 2007), suggesting that JNK3 deletion was having an effect very early on in oligodendrocyte survival, which is indicative of inhibiting demyelination.

In addition to oligodendrocytes, p75 is also expressed by neurons after SCI, suggesting that LM11A-31 might act on p75 to modulate its signaling in neurons, thereby affecting their regenerative capacity. P75 was shown to function as a coreceptor for $\mathrm{NgR}$ in response to myelin inhibitory molecules and thereby activate RhoA (Wang et al., 2002; Wong et al., 2002). It is possible therefore that LM11A-31 might interfere with p75-NgR interaction in the presence of myelin inhibitory molecules. We believe this is unlikely, however, mainly because there was no increase in regeneration in p75-null mice after SCI (Song et al., 2004; Zheng et al., 2005). In addition, NF protein levels were not different with LM11A-31 administration compared with vehicle control based on both immunohistochemical and biochemical analyses. We therefore conclude that the functional improvement that was observed with LM11A-31 is most likely due to inhibiting p75 signaling in oligodendrocytes. We should add, however, that we cannot rule out the possibility that decreased axonal degeneration among p75expressing neurons resulted in increased oligodendrocyte survival and also in improved functional outcome that we reported here. As is the case with any small molecule therapy, one cannot completely rule out other mechanisms of action and further studies will be required to fully explore other potential targets or modes of action.

It is possible that LM11A-31 blocks binding of other proand/or mature neurotrophins to p75 after SCI. We believe it is highly unlikely that other neurotrophins in addition to proNGF are being targeted by LM11A-31 in SCI. The pharmacophore features of LM11A-31 resemble $\beta$-turn loop 1 in NGF and NT3, and not brain-derived neurotrophic factor (BDNF) (Massa et al., 2006). In addition, it is NGF whose mRNA levels are known to be upregulated after injury in the CNS, but not BDNF nor NT3 mRNA. In particular, we have previously reported that proNGF and not proBDNF nor proNT3 that was secreted after injury in the CNS (Harrington et al., 2004).

In terms of potential clinical application, the dose is modest and delivery is feasible within the $4 \mathrm{~h}$, postinjury window for oral drug administration. The $100 \mathrm{mg} / \mathrm{kg}$ dose that we found optimally effective in mice translates to a modest $600 \mathrm{mg}$ dose to a 70 $\mathrm{kg}$ human, using the Food and Drug Administration-advised, body surface area conversion method (Reagan-Shaw et al., 2008).
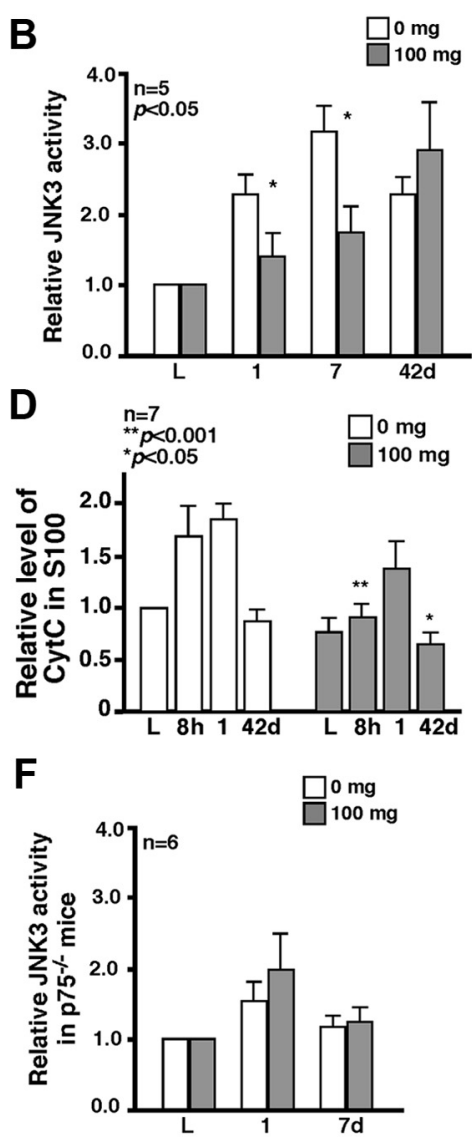

Figure 13. LM11A-31 attenuates the apoptotic response after $\mathrm{SCl}$ via targeting p75. $\boldsymbol{A}$, JNK3 activity was decreased with LM11A-31 at $100 \mathrm{mg} / \mathrm{kg}$. JNK3 activity was measured in immunoprecipitation/kinase assays. $\boldsymbol{B}$, Quantification of JNK3 activity. $11 \mathrm{~A}$ targets p75 after SCl. JNK3 activity was measured in p75 $5^{-1-}$ mice with and without $100 \mathrm{mg} / \mathrm{kg}$ LM11A-31. F, Quantification of JNK3 activity. ${ }^{*} p<0.05$ (Student's $t$ test).

Formal adsorption, distribution, metabolism, excretion and toxicity studies for LM11A-31 are currently underway.

In conclusion, we present the first successful example of a noninvasive, mechanism-based SCI therapy that targets a novel mechanism to achieve sparing of oligodendrocytes and myelin in mice. The small molecule, LM11A-31, crosses the blood-brain and blood-spinal cord barriers efficiently, and improves motor coordination without eliciting additional pain or weight loss. As intended to target p75 from the outset, LM11A-31 inhibits proNGF binding to p75 and its apoptotic JNK3 signaling, thereby increasing oligodendrocyte survival and subsequent myelin sparing. In this study, LM11A-31 administration was initiated beginning $4 \mathrm{~h}$ after injury. Since oligodendrocytes continue to undergo cell death in a progressive manner $>450 \mathrm{~d}$ after the initial injury (Totoiu and Keirstead, 2005), it will be of interest to test whether further delayed administration of LM11A-31 will have a similar effect and also how long a delay is allowable for optimum recovery. The long therapeutic window available in targeting oligodendrocytes is an advantage that can be explored based on our data presented here. In addition, since our investigation was terminated at $\sim 10 \%$ of the usual degeneration period, it may be of interest to examine the long-term persistence of tissue concentrations and effects, and perhaps explore repeated administration of LM11A-31 during an extended period that includes the entire degeneration period. 


\section{References}

Abott NJ (2004) Prediction of blood-brain barrier permeation in drug discovery from in vivo, in vitro and in silico models. Drug Discov Today Technol 1:407-416. CrossRef

Basso DM, Fisher LC, Anderson AJ, Jakeman LB, McTigue DM, Popovich PG (2006) Basso mouse scale for locomotion detects differences in recovery after spinal cord injury in five common mouse strains. J Neurotrauma 23:635-659. CrossRef Medline

Beattie MS, Harrington AW, Lee R, Kim JY, Boyce SL, Longo FM, Bresnahan JC, Hempstead BL, Yoon SO (2002) ProNGF induces p75-mediated death of oligodendrocytes following spinal cord injury. Neuron 36:375386. CrossRef Medline

Bennett GJ, Xie YK (1988) A peripheral mononeuropathy in rat that produces disorders of pain sensation like those seen in man. Pain 33:87-107. CrossRef Medline

Bentley CA, Lee KF (2000) p75 is important for axon growth and schwann cell migration during development [In Process Citation]. J Neurosci 20: 7706-7715. Medline

Biernaskie J, Sparling JS, Liu J, Shannon CP, Plemel JR, Xie Y, Miller FD, Tetzlaff W (2007) Skin-derived precursors generate myelinating Schwann cells that promote remyelination and functional recovery after contusion spinal cord injury. J Neurosci 27:9545-9559. CrossRef Medline

Bradbury EJ, Moon LD, Popat RJ, King VR, Bennett GS, Patel PN, Fawcett JW, McMahon SB (2002) Chondroitinase ABC promotes functional recovery after spinal cord injury. Nature 416:636-640. CrossRef Medline

Busch SA, Silver J (2007) The role of extracellular matrix in CNS regeneration. Curr Opin Neurobiol 17:120-127. CrossRef Medline

Cao Q, Xu XM, Devries WH, Enzmann GU, Ping P, Tsoulfas P, Wood PM, Bunge MB, Whittemore SR (2005) Functional recovery in traumatic spinal cord injury after transplantation of multineurotrophin-expressing glial-restricted precursor cells. J Neurosci 25:6947-6957. CrossRef Medline

Cao Q, He Q, Wang Y, Cheng X, Howard RM, Zhang Y, DeVries WH, Shields CB, Magnuson DS, Xu XM, Kim DH, Whittemore SR (2010) Transplantation of ciliary neurotrophic factor-expressing adult oligodendrocyte precursor cells promotes remyelination and functional recovery after spinal cord injury. J Neurosci 30:2989-3001. CrossRef Medline

Crowe MJ, Bresnahan JC, Shuman SL, Masters JN, Beattie MS (1997) Apoptosis and delayed degeneration after spinal cord injury in rats and monkeys [published erratum appears in Nat Med 1997 Feb;3:240]. Nat Med 3:73-76. CrossRef Medline

David S, Kroner A (2011) Repertoire of microglial and macrophage responses after spinal cord injury. Nat Rev Neurosci 12:388-399. CrossRef Medline

Demjen D, Klussmann S, Kleber S, Zuliani C, Stieltjes B, Metzger C, Hirt UA, Walczak H, Falk W, Essig M, Edler L, Krammer PH, Martin-Villalba A (2004) Neutralization of CD95 ligand promotes regeneration and functional recovery after spinal cord injury. Nat Med 10:389-395. CrossRef Medline

Gullo M, Hochreutener, E., Schnell, D., Scholl, J., Schwab, M.E., and Schnell, L. (2008) The Schnell Swim Test (SST) to measure motor function and recovery in spinal cord injured rats. Paper presented at the 6th International Conference on Methods and Techniques in Behavioral Research, Maastricht, The Netherlands, August. Proceedings of Measuring Behavior, p. 35-36.

Harrington AW, Leiner B, Blechschmitt C, Arevalo JC, Lee R, Mörl K, Meyer M, Hempstead BL, Yoon SO, Giehl KM (2004) Secreted proNGF is a pathophysiological death-inducing ligand after adult CNS injury. Proc Natl Acad Sci U S A 101:6226-6230. CrossRef Medline

Hofstetter CP, Holmström NA, Lilja JA, Schweinhardt P, Hao J, Spenger C, Wiesenfeld-Hallin Z, Kurpad SN, Frisén J, Olson L (2005) Allodynia limits the usefulness of intraspinal neural stem cell grafts; directed differentiation improves outcome. Nat Neurosci 8:346-353. CrossRef Medline

Hoschouer EL, Basso DM, Jakeman LB (2010) Aberrant sensory responses are dependent on lesion severity after spinal cord contusion injury in mice. Pain 148:328-342. CrossRef Medline

Karimi-Abdolrezaee S, Eftekharpour E, Wang J, Morshead CM, Fehlings MG (2006) Delayed transplantation of adult neural precursor cells promotes remyelination and functional neurological recovery after spinal cord injury. J Neurosci 26:3377-3389. CrossRef Medline

Karimi-Abdolrezaee S, Eftekharpour E, Wang J, Schut D, Fehlings MG (2010) Synergistic effects of transplanted adult neural stem/progenitor cells, chondroitinase, and growth factors promote functional repair and plasticity of the chronically injured spinal cord. J Neurosci 30:1657-1676. CrossRef Medline

Keirstead HS, Nistor G, Bernal G, Totoiu M, Cloutier F, Sharp K, Steward O (2005) Human embryonic stem cell-derived oligodendrocyte progenitor cell transplants remyelinate and restore locomotion after spinal cord injury. J Neurosci 25:4694-4705. CrossRef Medline

Kigerl KA, Lai W, Rivest S, Hart RP, Satoskar AR, Popovich PG (2007) Tolllike receptor (TLR)-2 and TLR-4 regulate inflammation, gliosis, and myelin sparing after spinal cord injury. J Neurochem 102:37-50. CrossRef Medline

Kim GM, Xu J, Song SK, Yan P, Ku G, Xu XM, Hsu CY (2001) Tumor necrosis factor receptor deletion reduces nuclear factor-kappaB activation, cellular inhibitor of apoptosis protein 2 expression, and functional recovery after traumatic spinal cord injury. J Neurosci 21:6617-6625. Medline

Kwon BK, Okon E, Hillyer J, Mann C, Baptiste D, Weaver LC, Fehlings MG, Tetzlaff W (2011) A systematic review of non-invasive pharmacologic neuroprotective treatments for acute spinal cord injury. J Neurotrauma 28:1545-1588. CrossRef Medline

Lee KF, Li E, Huber LJ, Landis SC, Sharpe AH, Chao MV, Jaenisch R (1992) Targeted mutation of the gene encoding the low affinity NGF receptor p75 leads to deficits in the peripheral sensory nervous system. Cell 69: 737-749. CrossRef Medline

Lewin GR, Ritter AM, Mendell LM (1993) Nerve growth factor-induced hyperalgesia in the neonatal and adult rat. J Neurosci 13:2136-2148. Medline

Li QM, Tep C, Yune TY, Zhou XZ, Uchida T, Lu KP, Yoon SO (2007) Opposite regulation of oligodendrocyte apoptosis by JNK3 and Pin 1 after spinal cord injury. J Neurosci 27:8395-8404. CrossRef Medline

Liebscher T, Schnell L, Schnell D, Scholl J, Schneider R, Gullo M, Fouad K, Mir A, Rausch M, Kindler D, Hamers FP, Schwab ME (2005) Nogo-A antibody improves regeneration and locomotion of spinal cord-injured rats. Ann Neurol 58:706-719. CrossRef Medline

Lipinski CA, Lombardo F, Dominy BW, Feeney PJ (2001) Experimental and computational approaches to estimate solubility and permeability in drug discovery and development settings. Adv Drug Deliv Rev 46:3-26. CrossRef Medline

Liu J, Lillo C, Jonsson PA, Vande Velde CV, Ward CM, Miller TM, Subramaniam JR, Rothstein JD, Marklund S, Andersen PM, Brännström T, Gredal O, Wong PC, Williams DS, Cleveland DW (2004) Toxicity of familial ALS-linked SOD1 mutants from selective recruitment to spinal mitochondria. Neuron 43:5-17. CrossRef Medline

Liu K, Lu Y, Lee JK, Samara R, Willenberg R, Sears-Kraxberger I, Tedeschi A, Park KK, Jin D, Cai B, Xu B, Connolly L, Steward O, Zheng B, He Z (2010) PTEN deletion enhances the regenerative ability of adult corticospinal neurons. Nat Neurosci 13:1075-1081. CrossRef Medline

Liu X, Kim CN, Yang J, Jemmerson R, Wang X (1996) Induction of apoptotic program in cell-free extracts: requirement for dATP and cytochrome c. Cell 86:147-157. CrossRef Medline

Marchenko ND, Zaika A, Moll UM (2000) Death signal-induced localization of $\mathrm{p} 53$ protein to mitochondria. A potential role in apoptotic signaling. J Biol Chem 275:16202-16212. CrossRef Medline

Massa SM, Xie Y, Yang T, Harrington AW, Kim ML, Yoon SO, Kraemer R, Moore LA, Hempstead BL, Longo FM (2006) Small, nonpeptide p75NTR ligands induce survival signaling and inhibit proNGF-induced death. J Neurosci 26:5288-5300. CrossRef Medline

McDonald JW, Althomsons SP, Hyrc KL, Choi DW, Goldberg MP (1998) Oligodendrocytes from forebrain are highly vulnerable to AMPA/kainate receptor-mediated excitotoxicity. Nat Med 4:291-297. CrossRef Medline

Nykjaer A, Lee R, Teng KK, Jansen P, Madsen P, Nielsen MS, Jacobsen C, Kliemannel M, Schwarz E, Willnow TE, Hempstead BL, Petersen CM (2004) Sortilin is essential for proNGF-induced apoptosis. Nature 427: 843-848. CrossRef Medline

Ohori Y, Yamamoto S, Nagao M, Sugimori M, Yamamoto N, Nakamura K, Nakafuku M (2006) Growth factor treatment and genetic manipulation stimulate neurogenesis and oligodendrogenesis by endogenous neural progenitors in the injured adult spinal cord. J Neurosci 26:11948-11960. CrossRef Medline

Ohri SS, Maddie MA, Zhao Y, Qiu MS, Hetman M, Whittemore SR (2011) Attenuating the endoplasmic reticulum stress response improves func- 
tional recovery after spinal cord injury. Glia 59:1489-1502. CrossRef Medline

Park KK, Liu K, Hu Y, Smith PD, Wang C, Cai B, Xu B, Connolly L, Kramvis I, Sahin M, He Z (2008) Promoting axon regeneration in the adult CNS by modulation of the PTEN/mTOR pathway. Science 322:963-966. CrossRef Medline

Pearse DD, Pereira FC, Marcillo AE, Bates ML, Berrocal YA, Filbin MT, Bunge MB (2004) cAMP and Schwann cells promote axonal growth and functional recovery after spinal cord injury. Nat Med 10:610-616. CrossRef Medline

Pinzon A, Marcillo A, Quintana A, Stamler S, Bunge MB, Bramlett HM, Dietrich WD (2008) A re-assessment of minocycline as a neuroprotective agent in a rat spinal cord contusion model. Brain Res 1243:146-151. CrossRef Medline

Reagan-Shaw S, Nihal M, Ahmad N (2008) Dose translation from animal to human studies revisited. FASEB J 22:659-661. Medline

Ro LS, Chen ST, Tang LM, Jacobs JM (1999) Effect of NGF and anti-NGF on neuropathic pain in rats following chronic constriction injury of the sciatic nerve. Pain 79:265-274. CrossRef Medline

Saganov á K, Orendácov á J, Cizkov á D, Vanick ý I (2008) Limited minocycline neuroprotection after balloon-compression spinal cord injury in the rat. Neurosci Lett 433:246-249. CrossRef Medline

Smith RR, Burke DA, Baldini AD, Shum-Siu A, Baltzley R, Bunger M, Magnuson DS (2006) The Louisville Swim Scale: a novel assessment of hindlimb function following spinal cord injury in adult rats. J Neurotrauma 23:1654-1670. CrossRef Medline

Song XY, Zhong JH, Wang X, Zhou XF (2004) Suppression of p75NTR does not promote regeneration of injured spinal cord in mice. J Neurosci 24: 542-546. CrossRef Medline
Sun F, He Z (2010) Neuronal intrinsic barriers for axon regeneration in the adult CNS. Curr Opin Neurobiol 20:510-518. CrossRef Medline

Totoiu MO, Keirstead HS (2005) Spinal cord injury is accompanied by chronic progressive demyelination. J Comp Neurol 486:373-383. CrossRef Medline

Wang KC, Kim JA, Sivasankaran R, Segal R, He Z (2002) P75 interacts with the Nogo receptor as a co-receptor for Nogo, MAG and OMgp. Nature 420:74-78. CrossRef Medline

Wong ST, Henley JR, Kanning KC, Huang KH, Bothwell M, Poo MM (2002) A p75(NTR) and Nogo receptor complex mediates repulsive signaling by myelin-associated glycoprotein. Nat Neurosci 5:1302-1308. CrossRef Medline

Yune TY, Lee JY, Jung GY, Kim SJ, Jiang MH, Kim YC, Oh YJ, Markelonis GJ, Oh TH (2007) Minocycline alleviates death of oligodendrocytes by inhibiting pro-nerve growth factor production in microglia after spinal cord injury. J Neurosci 27:7751-7761. CrossRef Medline

Zheng B, Atwal J, Ho C, Case L, He XL, Garcia KC, Steward O, TessierLavigne M (2005) Genetic deletion of the Nogo receptor does not reduce neurite inhibition in vitro or promote corticospinal tract regeneration in vivo. Proc Natl Acad Sci U S A 102:1205-1210. CrossRef Medline

Zheng GZ, Bhatia P, Kolasa T, Patel M, El Kouhen OF, Chang R, Uchic ME, Miller L, Baker S, Lehto SG, Honore P, Wetter JM, Marsh KC, Moreland RB, Brioni JD, Stewart AO (2006) Correlation between brain/plasma ratios and efficacy in neuropathic pain models of selective metabotropic glutamate receptor 1 antagonists. Bioorg Med Chem Lett 16:4936-4940. CrossRef Medline 